Page 1 of 1 1. EDT 628255
2. To: (Recelving Organization)

Project Development/Implementaton

5. Proj./Prog./Dept./Dlv.:

TWRS

8. Origlnator Remarks:

Please review and approve the attached Waste Feed Delivery Raw Water, Potable Water, and Compressed Air Capacity Evaluation $(\mathrm{RPQ}-5227)$.

11. Receiver Remarks:

11A. Design Baseline Document? $O$ Yes

No
3. From: (Originating Organization)

6. Design Authority/Design Agent/Cog. Engr.:

Thomas H. May
Project Definition

4. Related EDT No.:

N/A

7. Purchase Order No.:

$\mathrm{N} / \mathrm{A}$

9. Equip./Component No.:

$\mathrm{N} / \mathrm{A}$

10. System/BIdg./Facility:

DST Raw Water Dist

12. Major Assm. Dwg. No.:

13. Permit/Permit Application No.:

$\mathrm{N} / \mathrm{A}$

14. Required Response Date:

$2 / 13 / 00$

\begin{tabular}{|l|l|}
\hline \multicolumn{1}{|l|}{15.} \\
\hline $\begin{array}{c}\text { (A) } \\
\text { Item } \\
\text { No. }\end{array}$ & (B) Document/Drawing No. \\
\hline 1 & RPP-5227 \\
\hline & \\
\hline & \\
\hline & \\
\hline & \\
\hline & \\
\hline
\end{tabular}

16.

\begin{tabular}{|c|l|}
\hline Approval Designator (F) & \\
\hline $\begin{array}{c}\text { E, S, Q D OR N/A } \\
\text { (See WHC.CM-3-5, } \\
\text { Sec. 12.7) }\end{array}$ & $\begin{array}{l}\text { 1. Approval } \\
\text { 2. Release } \\
\text { 3. information }\end{array}$ \\
\hline
\end{tabular}

17.

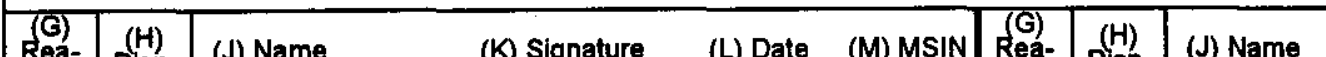

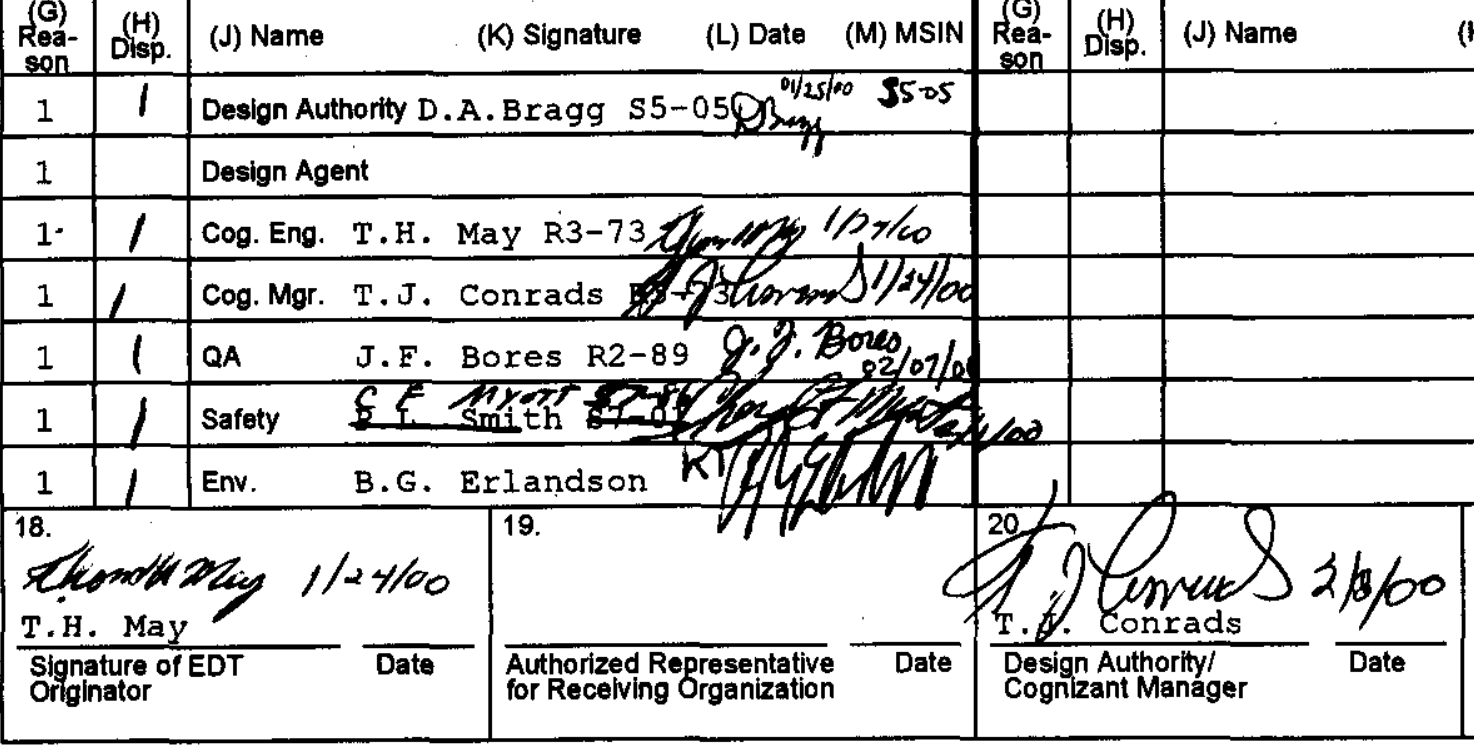

BD-7400-172-2 (10/97)
DATA TRANSMITTED

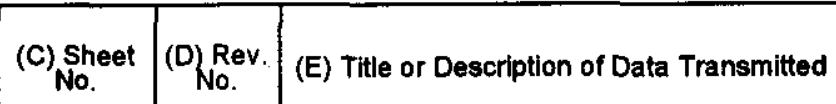

\begin{tabular}{|c|c|c|c|}
\hline (F) & $(G)$ & $(H)$ & $(l)$ \\
\hline $\begin{array}{c}\text { Approval } \\
\text { Desig- } \\
\text { nator }\end{array}$ & $\begin{array}{c}\text { Reason } \\
\text { mittal }\end{array}$ & $\begin{array}{c}\text { Origi- } \\
\text { nator } \\
\text { Dispo- } \\
\text { stion }\end{array}$ & $\begin{array}{c}\text { Recelv- } \\
\text { er } \\
\text { Dispo- } \\
\text { sition }\end{array}$ \\
\hline & & & \\
\hline
\end{tabular}

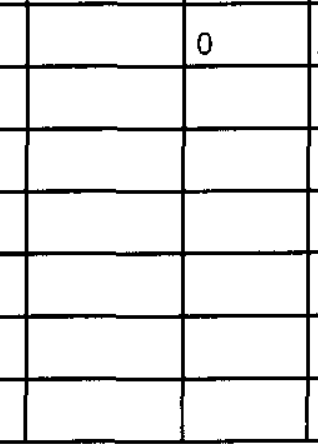

Air and Water Assessment
Reason for Transmittal (G)

4. Review
5. Post-Review
6. Dist. (Receipt Acknow. Required)
KEY

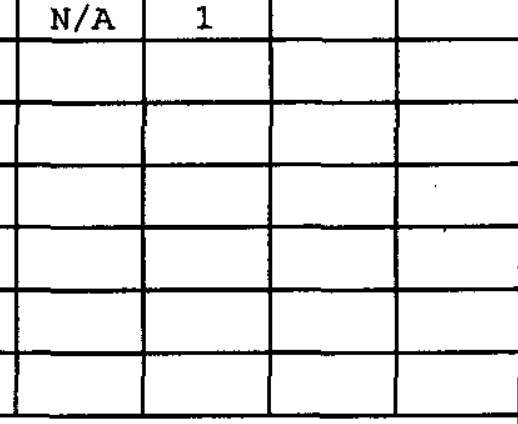

Disposition (H) \& (I)

$\begin{array}{ll}\text { 1. Approved } & \text { 4. Reviewed no/comment } \\ \text { 2. Approved w/comment } & \text { 5. Reviewed w/comment } \\ \text { 3. Disapproved w/comment } & \text { 6. Receipt acknowledged }\end{array}$

SIGNATURE/DISTRIBUTION
(See Approval Designator for required signatures)

(See Approval Designator for required signatures)

(K) Signature

(L) Date

21. DOE APPROVAL (if required) Ctri No.

Approved

Approved w/comments

Disapproved w/comments

(M) MSIN 


\title{
Waste Feed Delivery Raw Water, Potable Water, and Compressed Air Capacity Evaluation
}

\author{
Thomas H. May \\ CH2MHILL Hanford Group \\ Richland, WA 99352 \\ U.S. Department of Energy Contract DE-AC06-96RL13200 \\ EDT/ECN: 628254 \\ Org Code: UF130000 \\ UC: $\quad$ N/A \\ B\&R Code: N/A \\ Charge Code: 110299 \\ Total Pages: 63 \\ Key Words: Raw Water, Potable Water, Compressed Air
}

\begin{abstract}
:
This study evaluated the ability of the Raw Water, Potable water, and Compressed Air systems to support safe storage as well as the first phase of the Waste Feed Delivery. Several recommendations are made to improve the system.
\end{abstract}

TRADEMARK DISCLAIMER. Reference herein to any specific commercial product, process, or service by trade name, trademark, manufacturer, or otherwise, does not necessarily constltute or imply its endorsement, recommendation, or favoring by the United States Government or any agency thereof or its contractors or subcontractors.

Printed in the United States of America. To obtain coples of this document, contact: Document Control Services, P.O. Box 950, Mailstop H6-08, Richland WA 99352, Phone (509) 372-2420; Fax (509) 376-4989.
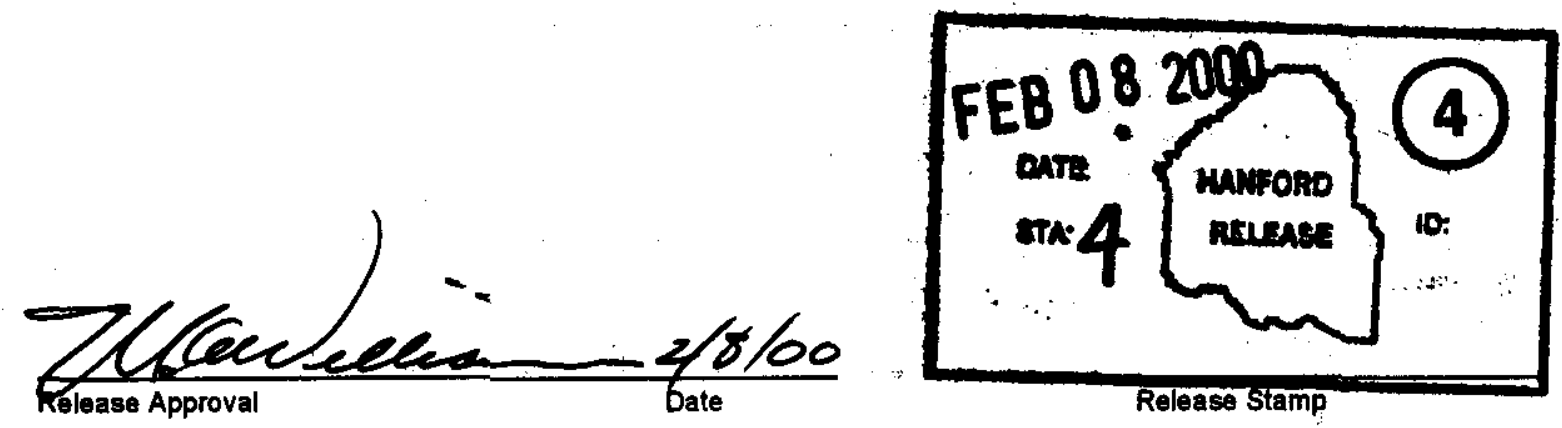

Approved For Public Release 


\section{WASTE FEED DELIVERY RAW WATER, POTABLE WATER, AND COMPRESSED AIR CAPACITY EVALUATION}

prepared for

\section{CH2M HILL HANFORD GROUP HOLMES \& NARVER \\ Contract 4412/Task 017 \\ (formerly Contract No. 677, Release 007) \\ Report No. 9905306-001 \\ Revision 0}

January 2000

Prepared by: C. M. Conselman Dave Haring Danny Mendoza Stephen Riesenweber Tom Salzano

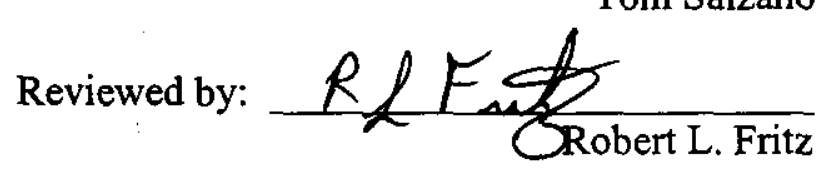
$\frac{1-21.00}{\text { Date }}$ 


\section{TABLE OF CONTENTS}

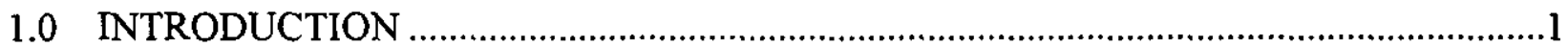

2.0 SCOPE

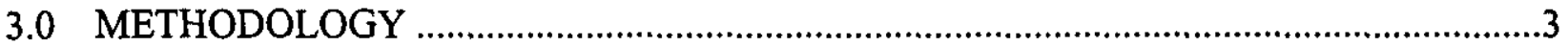

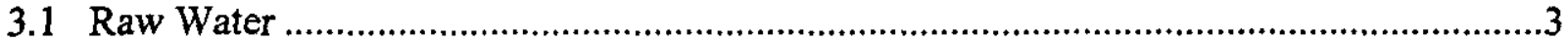

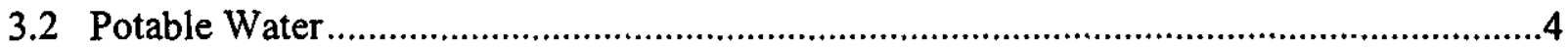

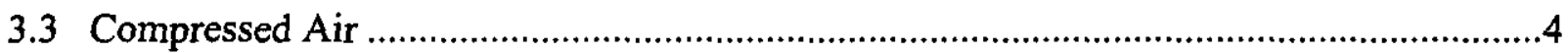

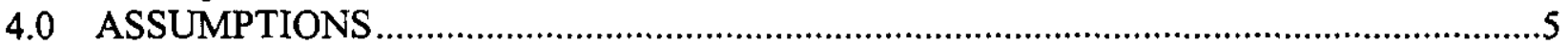

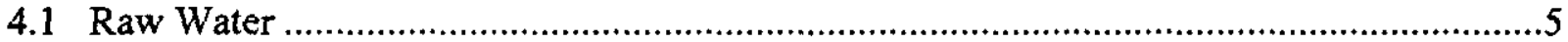

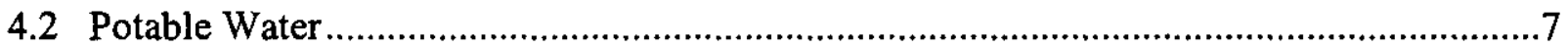

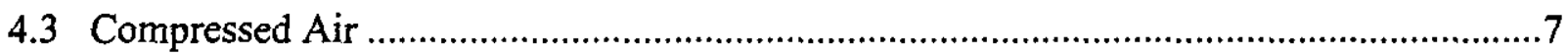

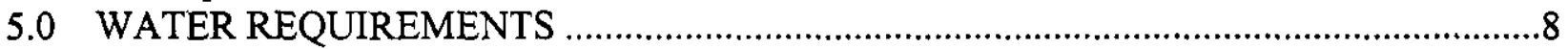

5.1 Water Quality Requirements....................................................................................

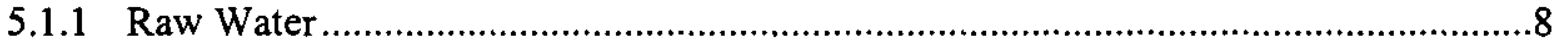

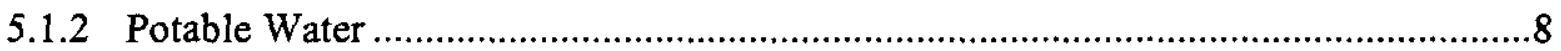

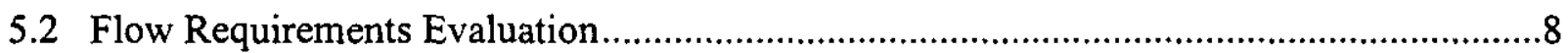

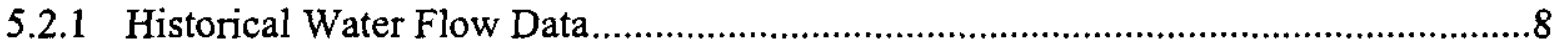

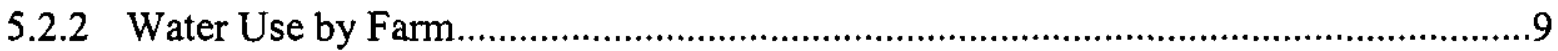

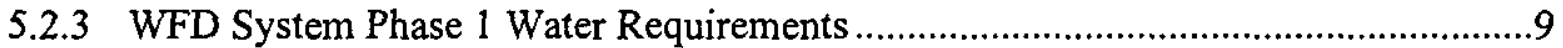

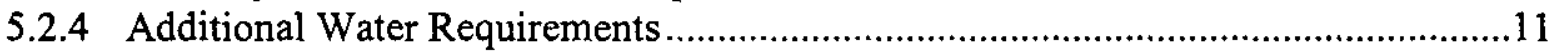

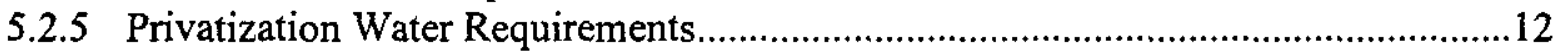

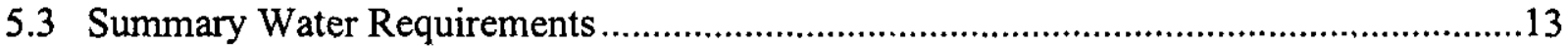

6.0 EVALUATION OF EXISTING CENTRAL PLATEAU WATER

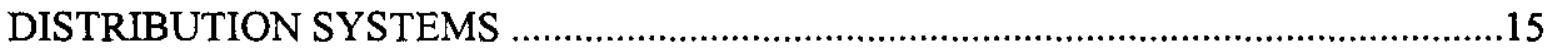

6.1 200 East Area Raw Water Distribution System.........................................................16

6.2 200 West Area Raw Water Distribution System …….................................................17

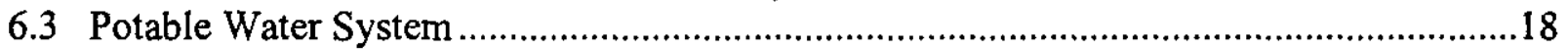

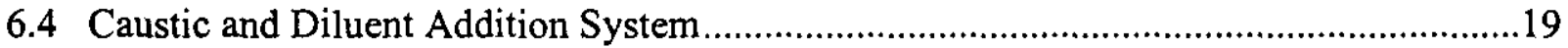

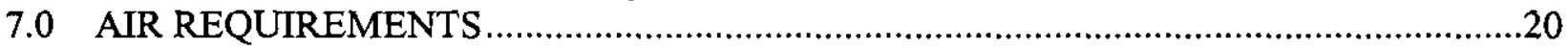

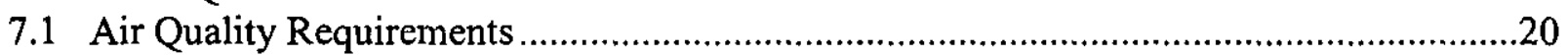

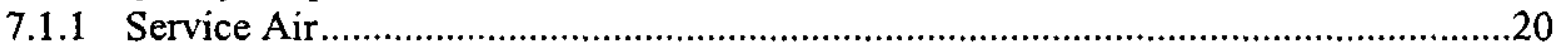

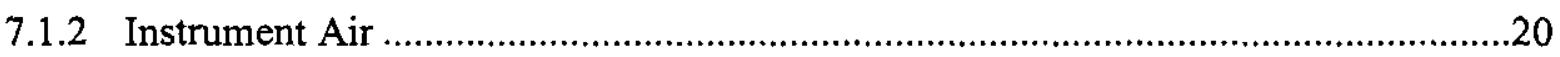

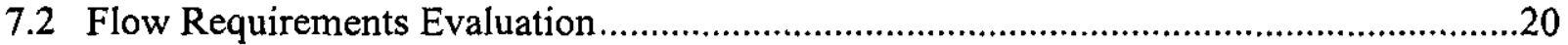

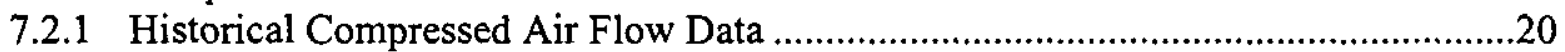

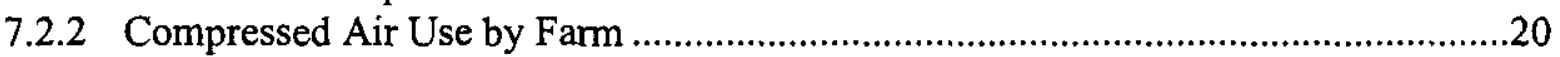

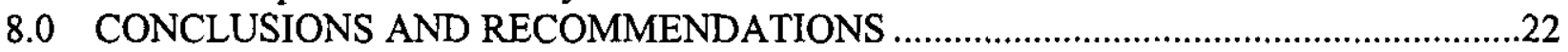

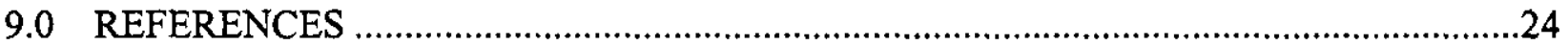

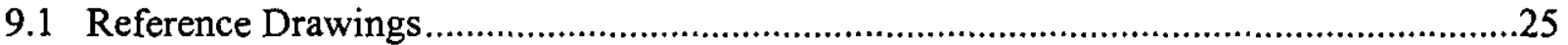

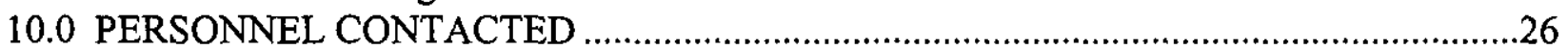


RPP-5227

REVISON 0

\section{APPENDICES}

Appendix A

Time-Phasing Data Histograms

Appendix B

Supporting Sketches

Appendix C

Potential Raw Water Uses by Farm

Appendix D

Potential Compressed Air Uses by Farm 
RPP-5227

REVISON 0

\section{TABLES}

Table 1. Historical Raw Water Demands. 8

Table 2. WFD System Phase 1 Estimated Peak Flowrate Demands. ...................................... 10

Table 3. 200 East Area Estimated Peak Simultaneous Raw Water Demands. ........................... 12

Table 4. 200 West Area Estimated Peak Simultaneous Raw Water Demands.......................... 13

Table 5. 200 East Area Estimated Raw Water Distribution System Peak Demands.................. 14

Table 6. 200 West Area Estimated Raw Water Distribution System Peak Demands. ............... 14

Table 7. Summary of Existing Piping Configuration ........................................................ 16

Table 8. Summary of Estimated Peak Process and Instrument Air Requirements..................... 21 
RPP-5227

REVISON 0

\section{ACRONYMS}

ALC
DST
gpm
HLW
HTWOS
kPa
LAW
lpm
m
mm
m/sec
NE
NW
PFP
psig
SE
SST
SW
TWRS
TWRS O\&UP
WAC
WESF
WFD
WRF

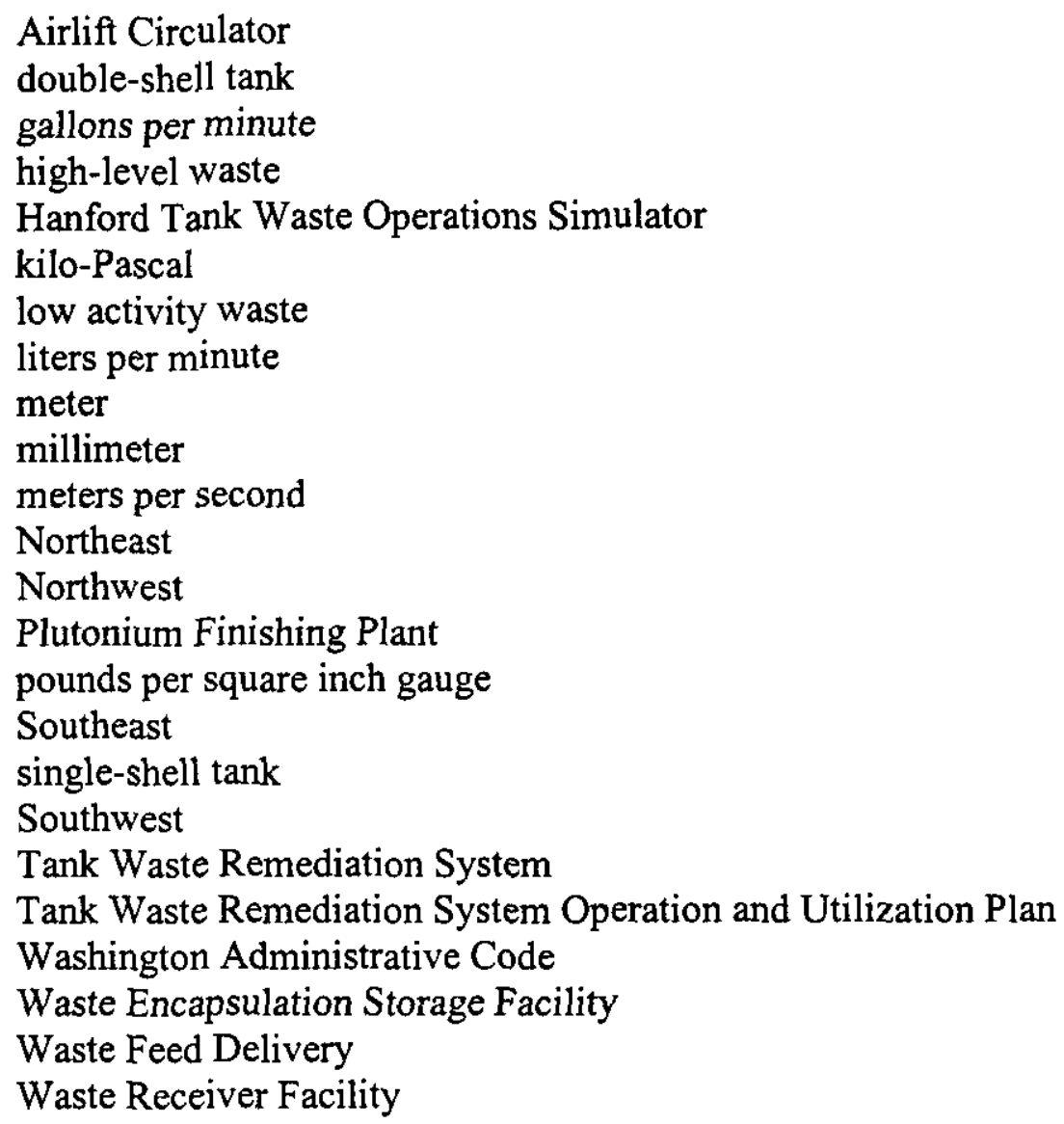




\subsection{INTRODUCTION}

The ability to provide waste feed delivery (WFD) to the Privatization Contractor's vitrification facility is a key element in the overall Hanford Site cleanup mission. A necessary element in accomplishing the WFD Program mission is the availability of raw water, potable water, and compressed air to support waste mobilization, transfer, and monitoring functions.

One aspect of this report addresses the capability of the 200 East and 200 West Area raw water distribution systems to meet the water flow demands required to support WFD activities. Raw water is required during WFD for the following operations:

- In-tank dilution and mixing of waste,

- Transfer pump and transfer line flushing operations,

- Flush water for sluicing wastes to retrieve tank sludges,

- In-line dilution of waste during transfers, and

- $\quad$ Mixer pump installation and operations.

In addition to the WFD activities, raw water will be required for other facility operations such as evaporator campaigns, tank farms dust control, and normal usage by other facilities such as Waste Encapsulation Storage Facility (WESF), U-Plant, Plutonium Finishing Plant (PFP), etc. Raw water is also required for retrieval of wastes both in the single-shell tanks (SSTs) and at the proposed Waste Receiver Facilities (WRFs).

A second aspect considered by this report is the availability of potable water. Potable water is required for facility personnel uses (i.e., drinking water, toilets, showers). WFD activities will require an increased number of construction and Operations personnel to accomplish the mission. This report evaluates Tank Farm potable water requirements, as well as evaluates the ability of the existing potable water system to meet the needs.

The final consideration of this report is the compressed air distribution system. Compressed air is used at Tank Farms for certain tank mixing/cooling, instrumentation, and ventilation systems. This report identifies existing and projected air uses and air quality requirements for Tank Farms, and evaluates the existing systems for ability to support the identified needs. 


\section{$2.0 \quad$ SCOPE}

This study identifies existing and projected raw water, potable water, and compressed air requirements from all users during the WFD System Phase 1 activities. The capability of the existing systems to meet these needs is also evaluated. Assessment of the cumulative raw water, potable water, and compressed air requirements in terms of quality, and flowrate needed to support upcoming activities of all known users is provided. The timeframe for which the requirements are estimated is 2003 to 2020 . 


\subsection{METHODOLOGY}

The performance of this evaluation was accomplished through the compilation and analysis of information from many sources, including previous studies, historical flow data, drawings, project planning information, facility/project personnel interviews, and outyear programmatic planning. The following items identify the approaches and sources used to generate the information contained in the remaining sections of this report. Assumptions are contained in Section 4.0, while conclusions and recommendations are contained in Section 8.0.

\subsection{Raw Water}

- Current and historical raw water usage at Tank Farms and other facilities supplied by the raw water distribution system were estimated from data provided by DynCorp Utilities personnel (see Section 10.0).

- Projected flow requirements for sluicing activities were estimated from historical information resulting from tank 241-C-106 sluicing experiences.

- Transfer dilution and flushing flow rates were estimated from Tank Farm facility personnel experience, Project W-211, "Initial Tank Retrieval Systems," data, and the WFD Level 2 Specifications.

- A letter report (Parazin 1998) addressed the capability of the existing 200 East Area raw water system to meet the demand for process flows to existing facilities, along with fire protection system process flow requirements at the Tank Waste Remediation System (TWRS) Privatization Contractor's site. Data from this report provides the basis for raw water demands for the Privatization Contractor.Raw water usage estimates for WFD System Phase 1 transfer and retrieval operations were obtained by evaluating the projected waste transfer data provided in HNF-SD-WM-SP-012, Rev. 1, Tank Waste Remediation System Operation and Utilization Plan, (TWRS O\&UP) (Kirkbride 1999), Table H-3. This document identifies the projected volumes of wastes to be retrieved and mobilized in support of WFD and the timeframe during which these activities are to occur. An electronic file of this data was received and sorted by tank farm and/or tank farm complex, then by start and end date of the activities. These data were plotted using scheduling software in order to determine timeframes where peak activities occurred (by tank farm and/or tank farm complex). Histograms were developed to determine overlap in activities where raw water usage occurred during each of these activities (see Appendix A). Peak raw water flows (contained in Section 5.0) were then estimated based on this evaluation.

- The capability of the existing Central Plateau Raw Water Systems to meet the requirements was assessed by evaluation and extrapolation of the hydraulic analysis results from Parazin (1998). This evaluation is provided in Section 6.0. 


\section{REVISON 0}

- A number of drawings (both essential and non-essential), and their outstanding Engineering Change Notices, were reviewed in order to determine the piping configuration and pipe sizes used in Section 6.0 (see Section 9.1).

\subsection{Potable Water}

- Current and historical potable water usage at Tank Farms and other facilities supplied by the potable water distribution system were estimated from data provided by DynCorp Utilities personnel (see Section 5.0).

- $\quad$ HNF-SD-WM-DRD-015, Rev. 1, Design Requirements Document for TWRS Privatization Phase I Raw and Potable Water Supply Systems, (Fort 1998) provided the basis for the potable water demands for the Privatization Contractor.

\subsection{Compressed Air}

- Current compressed air loads were obtained from facility drawings, operating procedures, and discussions with facility personnel. The results of this evaluation are contained in Section 7.0.

- Projects W-211 and W-521, "Waste Feed Delivery Systems," were evaluated for potential air requirements. 
RPP-5227

REVISON 0

\subsection{ASSUMPTIONS}

This assessment uses the assumptions identified below to establish the peak raw water, potable water, and compressed air requirements documented in this report.

\subsection{Raw Water}

- It is assumed that flowrates are the limiting/critical parameter in determining capability of the existing Central Plateau Raw Water Distribution System supplying water to the facilities within the scope of this evaluation. Total flow volumes are not critical to evaluating the adequacy of the distribution system. If desired, they can be obtained in other reports and/or by further assumptions and calculations based on liquid volumes provided in the Hanford Tank Waste Operations Simulator (HTWOS) and other documents.

- For non-Tank Farm facilities, facility-specific volumes and flowrate records were not available. It is assumed that raw water requirements for non-Tank Farm facilities (e.g., WESF, 222-S Labs, T-Plant, U-Plant, PFP, etc.) will not require flowrates above those that contribute to historical demands seen at the area-wide utility flowmeters monitoring the 200 East and 200 West Areas (as shown in Table 1 on Page 6). In addition, it is assumed that water requirements for safe storage within the Tank Farms (dust control, saltwell pumping, etc.) will not require flowrates above this same historical demand.

- It is assumed that for peak flowrates, post transfer line flushing is equivalent to the required transfer flowrate for suspension of solids. This flowrate is $530 \mathrm{lpm}$ (140 gpm) (LMHC 1999).

- It is assumed that the peak flowrates required for in-line and in-tank dilution will be $530 \mathrm{lpm}(140 \mathrm{gpm})$. The basis for this assumption is the plan to begin solids bearing transfers with 100 percent diluent and then gradually reduce the dilution flowrate until the proper waste characteristics are achieved.

- It is assumed that a negligible flowrate is required during mixer pump operation. A flowrate of $190 \mathrm{lpm}(50 \mathrm{gpm})$ to $380 \mathrm{lpm}(100 \mathrm{gpm})$ is estimated during mixer pump installation and removal to sluice in a new pump.

- Water volumes used for in-tank dilution are provided in Table H-3 of the TWRS O\&UP (Kirkbride 1999). Consistent with the HTWOS Program, only low activity waste (LAW) feed will require in-tank dilution. High-level waste (HLW) feed does not require water for in-tank dilution. It is assumed that supernate from other tanks will be pumped in and used for dilution of the HLW feed material. 
- Historical flow data from the tank 241-C-106 sluicing campaign was used as the basis for future SST sluicing activities. It is assumed that post sluicing flush water flowrates will be equivalent to transfer flowrates in order to maintain suspension of solids. Sluicing flowrates vary from a startup flowrate of $645 \mathrm{lpm}$ $(170 \mathrm{gpm})$, to an operating rate of $945 \mathrm{lpm}(250 \mathrm{gpm})$ to $1,475 \mathrm{lpm}(390 \mathrm{gpm})$, with a nominal flowrate of $1,325 \mathrm{lpm}(350 \mathrm{gpm})$. The value of $1,325 \mathrm{lpm}$ ( $350 \mathrm{gpm})$ will be used for estimating flush water flowrates associated with SST sluicing. This flowrate results in a velocity of over $2.4 \mathrm{~m} / \mathrm{sec}(8 \mathrm{ft} / \mathrm{sec})$.

- $\quad$ Per the TWRS O\&UP (Kirkbride 1999), Case 3, "SST Retrieval Sequence," it is assumed that two retrievals per farm from Tank Farms S, SX, A, AX, and C, and one activity in other farms, will occur simultaneously. Additionally, a maximum of six simultaneous retrievals per quadrant for Northwest (NW), Northeast (NE), and Southwest (SW) quadrants, a maximum of two simultaneous retrievals for Southeast (SE) quadrant, and seven maximum total ( $S W=U, S, S X, S Y$ Farms, $\mathrm{NW}=\mathrm{T}, \mathrm{TX}$, TY Farms, NE = B, BX, BY, SE = C, A, AX Farms) will occur during waste retrieval.

- It is assumed that Privatization Contractor's activities will require raw water usage from the utility distribution systems at flowrates documented in the Project W-519, "TWRS Privatization Phase I," water usage study (Parazin 1998).

- It is assumed that the raw water systems have adequate capacity to supply water to those Tank Farm activities occurring before the WFD System Phase 1 dates [e.g., saltwell pumping, double contained receiver tank to double-shell tank (DST) transfers of saltwell liquids, cross-site transfers of saltwell liquids, current safe storage activities, etc.]. Activities occurring before the October 10, 2003, date are assumed to be included in the raw water demand figures obtained from DynCorp Engineering (see Table 1).

- It is assumed that the current design for privatization is not to supply their fire systems with the site water system. All systems will be supplied from fire tanks sized according to their system demand. Raw water will be supplied to the edge of the property to fill the tank. There will be no increase demand from the raw water system for fire suppression.

- It is assumed that worst-case fire suppression demands is 9,465 lpm (2,500 gpm) for 200 East and 200 West Areas. This is based on worst-case fire suppression demands documented in FDH-9854235 R1 (Harper 1998). 
RPP-5227

REVISON 0

\subsection{Potable Water}

- It is assumed that no new potable water needs will be identified within the Tank Farms necessary to support WFD.

\subsection{Compressed Air}

- It is assumed that the ability to utilize the Airlift Circulators (ALCs) in 241-AW (tank 102 only), 241-AY, and 241-AZ Tank Farms will be retained. 


\subsection{WATER REQUIREMENTS}

\subsection{Water Quality Requirements}

\subsubsection{Raw Water}

The existing Central Plateau Raw Water System does not provide any filtration or other treatment of the water. It is assumed that conditioning will be provided on a case-by-case basis, with appropriate filtering systems provided by the end users.

\subsubsection{Potable Water}

Potable water is provided to Tank Farm facilities via a separate distribution system originating at the $283 \mathrm{~W}$ Water Treatment Facility located in the 200 West Area. Water quality is in accordance with the regulatory requirements provided in Washington Administrative Code (WAC) Chapter 246-290, "Group A Public Water Systems" (WAC 1999).

\subsection{Flow Requirements Evaluation}

\subsubsection{Historical Water Flow Data}

The average daily raw water flowrates and peak raw water flow rates for the 200 East and 200 West Areas were obtained from flow meter data compiled by DynCorp Utilities.

Flowmeters are housed in the 282-EC and 282-WC Buildings located in the 200 East and 200 West Areas, respectively. These meters monitor flows in the $0.6 \mathrm{~m}$ (24-in.) export water lines heading into the 200 East and 200 West Areas. The data obtained from DynCorp Utilities is indicative of water usage between June 10, 1999, and August 24, 1999. Table 1 provides average and peak water flowrates obtained from this data.

Table 1. Historical Raw Water Demands.

\begin{tabular}{|l|c|r|}
\hline \multicolumn{1}{|c|}{ Flowmeter Location } & $\begin{array}{c}\text { Peak Demand } \\
\text { (lpm/gpm) }\end{array}$ & $\begin{array}{c}\text { Average Demand } \\
\text { (lpm/gpm) }\end{array}$ \\
\hline 282-EC (East Area) & $24,751 / 6,538$ & $4,425 / 1,169$ \\
\hline 282-WC (West Area) & $5,400 / 1,426$ & $445 / 117$ \\
\hline
\end{tabular}

Water flowmeters are available at the 200 West Area, TX and SY Tank Farms. In the 200 East Area, flowrates are not available on a farm-by-farm basis because flowmeters are not provided on the water lines entering these tank farms. At the Tank Farms, metering is performed by flow totalizers at the Tank Farm Service Water Pits. These totalizers are monitored by Tank 
Farm Operations when water is required in the farms. Water volumes in units of gallons are recorded, but time durations to support calculation of flowrates needed are not recorded.

Since flowrates on a farm-by-farm basis are not available at all tank farms, it is assumed (for the purposes of this assessment) that the peak demands shown in Table 1 reflect raw water required for current safe storage of wastes, as well as water required for other non-Tank Farm facilities. The 200 East Area peak demand includes Tank Farms' usage for dust control, transfer line flushes, 242-A Evaporator campaigns, and other facilities usage (WESF, 204-AR, 244-AR, 244-CR, etc.). Facility personnel indicate that the 242-A Evaporator (a primary contributor to the 200 East Area peak flowrate) uses as much as $9,840 \mathrm{lpm}(2,600 \mathrm{gpm})$ during certain stages of operation. The 200 West Area peak demand includes Tank Farms' usage for transfer flushes, tanker truck fill for saltwell pumping, potable water (to both 200 East and 200 West Areas) and usage by other facilities (T-Plant, 222-S Labs, PFP, etc.).

\subsubsection{Water Use by Farm}

As a result of waste minimization efforts, there are currently only minimal uses of water within the Tank Farms. All raw water used in farms is either estimated as intermittent usage (less frequent than once per week but more frequent than once per month) or infrequent (less frequent than once per month). The most frequent use of water in the farms is the flushing of transfer lines and associated equipment following a waste transfer. Provisions are available in the farms for flushing process pits, risers, waste intrusive equipment, and instrumentation (i.e., dip tubes, ALCs, level indicator plummets). Although available, these provisions are rarely used and are not precisely quantifiable. The WFD System Phase 1 will include the installation of new transfer and mixer pumps in several of the DSTs; some of which will have filtered raw water connections for column filling and seal flushing. These pumps will also require the use of raw water (via the Diluent/Caustic Addition and Service Water systems) for waste dilution and pump flushing. Appendix $\mathrm{C}$ contains a breakdown of these potential uses of raw water by farm.

\subsubsection{WFD System Phase 1 Water Requirements}

Water requirements for WFD System Phase 1 were determined by evaluating the activities that are scheduled to commence October 20, 2003, for HLW feed, and May 2005 for LAW feed, and to continue up through 2020. The tank farms and specific tanks scheduled for Case 3 LAW feed include: AN Farm tanks 241-AN-102, 241-AN-103, 241-AN-104, 241-AN105, 241-AN-107; AZ Farm tanks 241-AZ-101, 241-AZ-102; AW Farm tanks 241-AW-101, 241-AW-104; AP Farm tanks 241-AP-101, 241-AP-104, 241-AP-105; and SY Farm tank 241SY-101. The tank farms and specific tanks targeted for HLW feed include AZ Farm tanks 241AZ-101, 241-AZ-102; AY Farm tanks 241-AY-101, 241-AY-102; AW Farm tanks 241-AW103, 241-AW-105; C Farm tanks 241-C-102, 241-C-104; and SY Farm tank 241-SY-102.

The TWRS O\&UP (Kirkbride 1999), Table H-3 (Case 3), was used as the basis for determining the types of activities that would require raw water and the timeframe in which the water would be needed. An electronic copy of the TWRS O\&UP, Table H-3, "Projected Transfers Through December 2019 For Case 3," was obtained and the WFD System Phase 1 
activities were sorted on a farm-by-farm basis and then sorted by date. Using time-phased bins of one month, histograms (see Appendix A) were plotted for the sorted data to provide information regarding multiple activities occurring within the month timeframe. Schedules were also plotted in order to assist in determining concurrent activities and types of activities requiring water, thus, providing a bounding case for each farm. In some cases, the histograms showed a number of activities occurring in a one-month timeframe. In these cases, a detailed review of the schedule dates in which the activities are to occur showed that fewer activities were actually scheduled concurrently. This lower value provides the basis for determining bounding peak demands.

Per Case 3 of the TWRS O\&UP (Kirkbride 1999), two SSTs (tanks 241-C-102 and 241C-104) are slated to be retrieved as part of the WFD System Phase 1. It is assumed that supernate for sluicing of these two SSTs will be obtained from the DST Receiver Tank. Raw water flowrates required for post-transfer flush are assumed to be equivalent to waste transfer flowrates. Data from the 241-C-106 sluicing campaign indicates that transfer flowrates are nominally $1,325 \mathrm{lpm}(350 \mathrm{gpm})$ and, therefore, the raw water flowrate required for flushing is $1,325 \mathrm{lpm}(350 \mathrm{gpm})$.

Table 2 provides estimated peak raw water demands for WFD System Phase 1 activities. Water for these activities will be provided to the diluent systems that heat and chemically treat water prior to flushing and dilution activities. Identification of the tanks contained within each complex/farm is shown earlier in this section.

Table 2. WFD System Phase 1 Estimated Peak Flowrate Demands.

\begin{tabular}{|c|c|c|c|c|}
\hline \multicolumn{5}{|c|}{200 East } \\
\hline Facility & Activity & $\begin{array}{c}\text { No. of Concurrent } \\
\text { Activities }\end{array}$ & $\begin{array}{l}\text { Projected Demand } \\
(\mathrm{lpm} / \mathrm{gpm})\end{array}$ & Notes \\
\hline $\begin{array}{l}\text { A Farm } \\
\text { Complex }\end{array}$ & $\begin{array}{l}\text { Flush/ } \\
\text { Dilution }\end{array}$ & $\overline{1}$ & $530 / 140$ & 1,4 \\
\hline AW Farms & Flush/Dilution & 1 & $530 / 140$ & 1,4 \\
\hline AP Farm & Flush/Dilution & 1 & $530 / 140$ & 1,4 \\
\hline C Farm & Sluicing & 1 & $1,325 / 350$ & 2,4 \\
\hline \multicolumn{3}{|l|}{ Total } & $2,915 / 770$ & \\
\hline \multicolumn{5}{|c|}{200 West } \\
\hline SY Farm & Flush/Dilution & 1 & $530 / 140$ & 3,4 \\
\hline \multicolumn{3}{|l|}{ Total } & $530 / 140$ & \\
\hline \multicolumn{3}{|c|}{ Total WFD System Phase 1 Demand } & $3,445 / 910$ & \\
\hline
\end{tabular}

\section{Notes:}

1. Post-transfer flushing, in-line and in-tank dilution/tank wash flowrates assumed to be $530 \mathrm{lpm}$ $(140 \mathrm{gpm})$ per event.

2. For sluicing activities, data from $241-\mathrm{C}-106$ was used. It is assumed that raw water will be required to be pumped for flushes at a flowrate equivalent to transfer flowrates. Flowrates for sluicing vary from $945 \mathrm{lpm}(250 \mathrm{gpm})$ to $1,475 \mathrm{lpm}(390 \mathrm{gpm})$ with the nominal flowrate of $1,325 \mathrm{lpm}(350 \mathrm{gpm})$.

3. WFD System Phase 1 transfers (SY DST to SY DST and cross-site) do not occur simultaneously per TWRS O\&UP (Kirkbride 1999), Table H-3.

4. Consistent with current Tank Farm activities, static water pressure of $758 \mathrm{kPa}(110 \mathrm{psig})$ is estimated to be sufficient (Harper 1998). Residual line pressure at the required flows can only be estimated with hydraulic analysis. 
RPP-5227

REVISON 0

\subsubsection{Additional Water Requirements}

There are a number of additional activities that are proposed to occur during the WFD System Phase 1 timeframe. These activities will impose additional demands on the raw water system within each tank farm, and in some cases, concurrent with WFD. These include:

- SST retrieval of the B Farm Complex, T-Farm Complex, and S/SX Farm,

- Receipt and staging of SST wastes at proposed WRFs,

- Tank farms safe storage uses (i.e., evaporator transfers)

- Transfer and staging of wastes not identified as WFD System Phase 1 activities but occurring within the WFD System Phase 1 timeframe.

Again, the TWRS O\&UP (Kirkbride 1999), Table H-3, was used to determine all of the activities planned for each respective tank farm. The tank farms were grouped into the following areas for the purposes of determining peak demands. Groupings are based on the proximity of farms to water distribution lines providing flow (see Appendix B). U Farm does not appear because no activities are planned for this facility during WFD System Phase 1.

EAST AREA

$\begin{array}{ll}\text { - } & \text { AN Farm } \\ \text { - } & \text { A-Complex, which } \\ \text { includes A, AX, AY, } \\ \text { and AZ Farms, } \\ \text { - } \\ \text { - } \\ \text { - } \\ \text { - } \\ \text { B } \\ \text { C C F Farm, Farm, } \\ \end{array}$

WEST AREA

- T/TX/TY, and

- S/SX/SY Farms.

Using a bin for one month, histograms were plotted (see Appendix A) for the sorted data to provide information regarding multiple activities occurring within the month timeframe for each of the groupings. In some cases, the histograms showed a number of activities occurring in a one-month timeframe. A review of the schedule dates showed that there were actually fewer activities that overlapped in time. These lower values provided the basis for determining peak demands. Tables 3 and 4 provide summaries of simultaneously occurring raw water demands by farm/complex. 
Table 3. 200 East Area Estimated Peak Simultaneous Raw Water Demands.

\begin{tabular}{|c|c|c|c|c|}
\hline Facility & Activity & $\begin{array}{l}\text { No. of Concurrent } \\
\text { Activities }\end{array}$ & $\begin{array}{l}\text { Projected Demand } \\
(\mathrm{lpm} / \mathrm{gpm})\end{array}$ & Notes \\
\hline $\begin{array}{l}\text { B/BX/BY } \\
\text { Farms }\end{array}$ & $\begin{array}{l}\text { WRF Flush/Dilution } \\
\text { Sluicing } \\
\text { Safe Storage } \\
\quad \text { Total } \\
\end{array}$ & $\begin{array}{l}3 \\
2\end{array}$ & $\begin{array}{r}1,590 / 420 \\
2,650 / 700 \\
\frac{0}{4} \\
4,240 / 1,120 \\
\end{array}$ & $\begin{array}{l}1,8 \\
2,8 \\
7,8\end{array}$ \\
\hline C Farm & $\begin{array}{l}\text { Sluicing } \\
\text { Safe Storage } \\
\quad \text { Total } \\
\end{array}$ & 1 & $\begin{array}{r}1,325 / 350 \\
380 / 100 \\
1,705 / 450 \\
\end{array}$ & $\begin{array}{l}, 8 \\
3,8\end{array}$ \\
\hline $\begin{array}{l}\text { A-Complex and } \\
\text { AN Farm }\end{array}$ & $\begin{array}{l}\text { Flush/Dilution } \\
\text { Sluicing } \\
\text { Safe Storage } \\
\quad \text { Total } \\
\end{array}$ & $\begin{array}{l}1 \\
2\end{array}$ & $\begin{array}{r}530 / 140 \\
2,650 / 700 \\
1,135 / 300 \\
4,315 / 1,140 \\
\end{array}$ & $\begin{array}{l}5,8 \\
3,8\end{array}$ \\
\hline AW Farm & $\begin{array}{c}\text { Flush/Dilution } \\
\text { Safe Storage } \\
\text { Total } \\
\end{array}$ & 5 & $\begin{array}{r}2,650 / 700 \\
3,30 / 100 \\
3,030 / 800 \\
\end{array}$ & $\begin{array}{l}6,8 \\
3,8\end{array}$ \\
\hline AP Farm & $\begin{array}{l}\text { Flush/Dilution } \\
\text { Safe Storage } \\
\text { Total }\end{array}$ & 4 & $\begin{array}{r}2,120 / 560 \\
380 / 100 \\
2,590 / 660 \\
\end{array}$ & $\begin{array}{l}6,8 \\
3,8\end{array}$ \\
\hline
\end{tabular}

Notes:

1. Flowrates are based on projected transfers shown in TWRS O\&UP (Kirkbride 1999), Table H-3 for waste retrieval facilities. Histogram shows six activities occurring in one month's timeframe.

Schedules show an overlap of three activities.

2. Per TWRS O\&UP (Kirkbride 1999), Table H-3, two simultaneous sluices are scheduled to occur.

3. Recent flow tests performed at AW Farm and flows observed were approximately $227 \mathrm{lpm}(60 \mathrm{gpm})$. A $38 \mathrm{~mm}(1-1.5$-in.) pipe provides water to each farm. A value of $380 \mathrm{lpm}(100 \mathrm{gpm})$ will be assumed where water is currently available at each farm in 200 East Area for safe storage.

4. Per TWRS O\&UP (Kirkbride 1999), Table H-3, one sluice activity is scheduled to occur.

5. Flowrates are based on projected transfers shown in TWRS O\&UP (Kirkbride 1999), Table H-3. Histogram shows seven activities occurring in a one-month timeframe. Schedules show an overlap of two sluices and one transfer.

6. Flowrates are based on projected transfers shown in TWRS O\&UP (Kirkbride 1999), Table H-3. Histogram shows six activities occurring in a one-month timeframe. Schedules show an overlap of five activities.

7. Current safe storage activities are in support of saltwell pumping. Saltwell pumping is scheduled to be completed by 2003 per the TWRS O\&UP (Kirkbride 1999), Table H-3. No additional safe storage demands are assumed.

8. Consistent with current Tank Farm activities, static water pressure of $758 \mathrm{kPa}(110 \mathrm{psig})$ is estimated to be sufficient (Harper 1998). Residual line pressure at the required flows can only be estimated with hydraulic analysis.

\subsubsection{Privatization Water Requirements}

The Privatization Contractor will use raw water from the 200 East Central Plateau Distribution System. A $0.3 \mathrm{~m}$ (12-in.) loop will be provided with one tap off an existing $0.3 \mathrm{~m}$ (12-in.) main east of AX Farm and one tap off of a new $0.3 \mathrm{~m}$ (12-in.) main south of AP Farm (see Appendix B, Figure 1). The flow requirements for the Privatization Contractor are:

- $\quad 1,250 \mathrm{lpm}(330 \mathrm{gpm})$ peak process flows at $517 \mathrm{kPa}(75 \mathrm{psig})$. 
Table 4. 200 West Area Estimated Peak Simultaneous Raw Water Demands.

\begin{tabular}{|c|l|c|r|c|}
\hline Facility & \multicolumn{1}{|c|}{ Activity } & $\begin{array}{c}\text { No. of Concurrent } \\
\text { Activities }\end{array}$ & $\begin{array}{c}\text { Projected Demand } \\
\text { (lpm/gpm) }\end{array}$ & Notes \\
\hline T/TX/TY Farms & WRF Flush/Dilution & 3 & $1,590 / 420$ & 1,6 \\
& Sluicing & 6 & $7,950 / 2,100$ & 2,6 \\
& Safe Storage & & 0 & 3,6 \\
& \multicolumn{1}{|c|}{ Total } & & $9,540 / 2,520$ & \\
\hline S/SX/SY Farms & WFD Flush/Dilution & 1 & $530 / 140$ & \\
& Sluicing & 2 & $2,650 / 700$ & 4,6 \\
& Safe Storage & & 0 & 5,6 \\
& \multicolumn{1}{|c|}{ Total } & & $3,180 / 840$ & \\
\hline
\end{tabular}

Notes:

1. Flowrates are based on projected transfers shown in TWRS O\&UP (Kirkbride 1999), Table H-3. Histogram shows seven activities occurring in a one-month timeframe, but review of the schedule dates reveal a maximum of three transfers occurring at one time.

2. Per TWRS O\&UP (Kirkbride 1999), Table H-3, six simultaneous sluices are scheduled to occur.

3. Current safe storage activities are in support of saltwell pumping. Saltwell pumping is scheduled to be completed by 2003 per the TWRS O\&UP, (Kirkbride 1999), Table H-3. No additional safe storage demands are assumed.

4. Per TWRS O\&UP (Kirkbride 1999), Table H-3, two simultaneous sluices are scheduled to occur.

5. Current safe storage demands are in support of saltwell pumping (tanker truck fills and cross-site transfers). Saltwell pumping is scheduled to be completed by 2003 per the TWRS O\&UP (Kirkbride 1999), Table H-3. No additional safe storage demands are assumed.

6. Consistent with current Tank Farm activities, static water pressure of $758 \mathrm{kPa}(110 \mathrm{psig})$ is estimated to be sufficient (Harper 1998). Residual line pressure at the required flows can only be estimated with hydraulic analysis.

\subsection{Summary Water Requirements}

The overall water distribution systems will provide water to the individual tank farm loads described in Tables 3 and 4, as well as to the following loads:

- Pretreatment/Privatization Contractor processing of wastes,

- 242-A Evaporator waste reduction campaigns,

- Shutdown/decontamination and decommissioning of miscellaneous facilities

(WESF, T-Plant, etc.),

- Tanker truck fill station usage,

- Environmental Restoration Disposal Facility

- 283-W Water Treatment Plant, and

- $\quad$ Fire hydrant testing/fire suppression/fire system testing.

Tables 5 and 6 provide a summary of the total peak raw water demands for both 200 East and 200 West Areas. 
RPP-5227

REVISON 0

Table 5. 200 East Area Estimated Raw Water Distribution System Peak Demands.

\begin{tabular}{|l|l|r|c|}
\hline \multicolumn{1}{|c|}{ Facility } & \multicolumn{1}{|c|}{ Activity } & \multicolumn{1}{c|}{$\begin{array}{c}\text { Projected Demand } \\
\text { (lpm/gpm) }\end{array}$} & Notes \\
\hline Tank Farm Loads & Flush/Dilution/Sluicing & $13,512 / 3,570$ & 1 \\
\hline Privatization Loads & Peak Process Flows & $1,250 / 330$ & 2 \\
\hline $\begin{array}{l}\text { Balance of 200 East } \\
\text { Area }\end{array}$ & $\begin{array}{l}\text { Safe Storage } \\
\text { 242-A Evaporator } \\
\text { Tanker Truck Fill Stations } \\
\text { Other Facilities (WESF, 204-AR, 244- } \\
\text { AR, 244-CR, etc.) } \\
\text { Fire Suppression (at 20 psig residual) }\end{array}$ & $24,755 / 6,540$ & 3 \\
& & \\
\hline Total & $9,465 / 2,500$ & 4 \\
\hline
\end{tabular}

Notes:

1. Data from Table 3.

2. Based on HNF-3363 (Parazin 1998) estimates for the privatization contractor.

3. Data from Table 1

4. Estimated from FDH-9854235.R1 (Harper 1998).

Table 6. 200 West Area Estimated Raw Water Distribution System Peak Demands.

\begin{tabular}{|l|l|c|c|}
\hline \multicolumn{1}{|c|}{ Facility } & \multicolumn{1}{|c|}{ Activity } & \multicolumn{1}{|c|}{$\begin{array}{c}\text { Projected } \\
\text { Demand } \\
\text { (lpm/gpm) }\end{array}$} & Notes \\
\hline Tank Farm Loads & Flush/Dilution/Sluicing & $12,720 / 3,360$ & 1 \\
\hline $\begin{array}{l}\text { Balance of 200 West } \\
\text { Area }\end{array}$ & $\begin{array}{l}\text { Safe Storage } \\
\text { Other Facilities (T-Plant, 222-S Labs, PFP, etc.) } \\
\text { Fire Suppression (at 20 psig residual) }\end{array}$ & $5,415 / 1,430$ & 2 \\
\hline \multicolumn{2}{|l}{ Total } & $9,465 / 2,500$ & 3 \\
\hline
\end{tabular}

Note:

1. Data from Table 4.

2. Data from Table 1.

3. Estimated from FDH-9854235 R1 (Harper 1998) 
RPP-5227

REVISON 0

\subsection{EVALUATION OF EXISTING CENTRAL PLATEAU WATER DISTRIBUTION SYSTEMS}

Water is pumped into the water distribution system via two identical pumping facilities located at the 100-B and 100-D Areas. The 181/182-B pumping facility in the 100-B Area serves as the primary source for RW, and the 182-D pump facility in 100-D Area is used as the backup supply. The facilities are kept fully operational, each consisting of four (4) fixed-speed pumps each having a rated capacity of $22,710 \mathrm{lpm}(6,000 \mathrm{gpm})$ and one (1) fixed-speed pump having a rated capacity of $11,355 \mathrm{lpm}(3,000 \mathrm{gpm})$ at $145 \mathrm{~m}(475 \mathrm{ft})$ of head. The pumps are configured in a parallel arrangement. Each facility has a rated capacity of $102,195 \mathrm{lpm}$ $(27,000 \mathrm{gpm})$ at $145 \mathrm{~m}(475 \mathrm{ft})$ of head. Two raw water booster pumps in 282-EC or 282-WC can be started (manual) when 200 East or 200 West raw water pressure drops below desired pressure. In addition, two (2) emergency fire pumps in 200 West Area and three (3) in 200 East Area provide additional flow when the raw water pressure drops to $415 \mathrm{kPa}(60 \mathrm{psig})$. These emergency pumps draw water off of existing 11.4 ML (3 Mgal) reservoirs to supply raw water and potable water demands.

Tables 5 and 6 in Section 5.3 of this report show that the worst-case raw water demands for the 200 East and 200 West Areas would be 48,982 lpm (12,940 gpm) and 27,600 lpm $(7,290 \mathrm{gpm})$, respectively. This is equivalent to a total raw water demand of $76,570 \mathrm{lpm}$ $(20,230 \mathrm{gpm})$. Although these water demands would not occur simultaneously, this total demand is only 75 percent of the capacity of the 182-B pump facility. Therefore, it is concluded that the existing raw water distribution pumps have sufficient capacity to support the requirements of the WFD in addition to the other concurrent loads placed on the system. The capability of the distribution piping supplying each farm to support the water demands shown in the tables is addressed in the following sections.

Complex network distribution systems are difficult to evaluate from a capacity perspective without hydraulic modeling/analysis. Typically, water distribution system piping is sized for a velocity of approximately $1.8 \mathrm{~m} / \mathrm{sec}(6 \mathrm{ft} / \mathrm{sec})$ with an upper limit of no more than 3 $\mathrm{m} / \mathrm{sec}(10 \mathrm{ft} / \mathrm{sec})$. As a first approximation, existing distribution piping has been evaluated at the projected flow rates to determine if it can support the water demands with a flow velocity of less than or equal to $2.4 \mathrm{~m} / \mathrm{sec}(8 \mathrm{ft} / \mathrm{sec})$. To account for pipe aging and fouling, the inside diameter of the existing pipe is reduced by $25 \mathrm{~mm}$ (1-in.). This degree of fouling is consistent with the observations of DynCorp Raw Water Utility personnel. A summary of the findings is shown in Table 7 below and figures showing the water distribution systems are provided in Appendix B. 
RPP-5227

REVISON 0

Table 7. Summary of Existing Piping Configuration.

\begin{tabular}{|c|c|c|c|c|}
\hline \multirow[b]{2}{*}{ Area/Farm } & \multicolumn{2}{|c|}{ Capacity Available } & \multirow[b]{2}{*}{$\begin{array}{c}\text { Capacity } \\
\text { Required } \\
\text { (lpm/gpm) }\end{array}$} & \multirow[b]{2}{*}{$\begin{array}{c}\text { System Meets } \\
\text { Demands? }\end{array}$} \\
\hline & Line Size (in) & $\begin{array}{c}\text { Capacity@ } \\
8 \mathrm{ft} / \mathrm{sec} \\
(\mathrm{lpm} / \mathrm{gpm})\end{array}$ & & \\
\hline 200 East Area & $24 / 16$ & $49,210 / 13,000$ & $48,982 / 12,940$ & Yes \\
\hline B/BX/BY Farms & 6 & $1,895 / 500$ & $4,240 / 1,120$ & No \\
\hline C Farm & 12 & $7,570 / 2,000$ & $1,705 / 450$ & Yes \\
\hline A-Complex and AN Farm & 12 & $5,865 / 1,550^{(1)}$ & $4,315 / 1,140$ & $\mathrm{Yes}^{(1)}$ \\
\hline AP & 12 & $10,410 / 2,750$ & $3,750 / 990^{(4)}$ & Yes \\
\hline $\mathrm{AW}$ & 14 & $11,360 / 3,000$ & $12,870 / 3,400^{(2)}$ & $\mathrm{Yes}^{(2)}$ \\
\hline 200 West Area & 20 & $24,605 / 6,500$ & $22,710 / 6,000^{(3)}$ & $\mathrm{Yes}^{(3)}$ \\
\hline T/TX/TY Farms & $4 / 4 / 6$ & $3,405 / 900$ & $9,540 / 2,520$ & No \\
\hline S/SX/SY Farms & $6 / 14$ & $<9,465 /<2,500$ & $3,180 / 840$ & Yes \\
\hline
\end{tabular}

Note:

1. Since the same line feeds the C Farm, the capacity is reduced by the $1,703 \mathrm{lpm}(450 \mathrm{gpm})$ required at $C$ Farm.

2. This includes $9,840 \mathrm{lpm}(2,600 \mathrm{gpm})$ for worst case operational needs at the $242-\mathrm{A}$ Evaporator. It is assumed that this load would not occur simultaneously with the peak water demand at AW Farm.

3. This is based on average safe storage demands. The total peak demand is $27,600 \mathrm{lpm}(7,290 \mathrm{gpm})$. If the velocity is increased to $3.5 \mathrm{~m} / \mathrm{sec}(11.5 \mathrm{ft} / \mathrm{sec})$ during this peak demand, the system has a capacity of $34,065 \mathrm{lpm}$ $(9,000 \mathrm{gpm})$.

4. This includes $1,250 \mathrm{lpm}$ (330gpm) of Raw Water projected for the Provocation Contractor.

\subsection{East Area Raw Water Distribution System}

Export water is fed to the 200 East Area in two $0.6 \mathrm{~m}$ (24-in.) lines to the 282-EC Building (see Appendix B). The raw water distribution system for the 200 East Area is fed with $0.6 \mathrm{~m}$ (24-in.) and $0.4 \mathrm{~m}$ (16-in.) raw water mains to supply the needs of the area. Considering fouling, these would be more like $0.38 \mathrm{~m}(15$-in.) and $0.58 \mathrm{~m}$ (23-in.) lines, respectively. As shown in Table 5, the projected peak raw water demand required for the $0.38 \mathrm{~m}$ (15-in.) and $0.58 \mathrm{~m}$ (23-in.) lines is $48,982 \mathrm{lpm}(12,940 \mathrm{gpm})$. At a velocity of $2.4 \mathrm{~m} / \mathrm{sec}(8 \mathrm{ft} / \mathrm{sec})$, a $0.38 \mathrm{~m}$ (15-in.) line can supply approximately $15,140 \mathrm{lpm}(4,000 \mathrm{gpm})$, while a $0.58 \mathrm{~m}$ (23-in.) line can supply approximately $34,070 \mathrm{lpm}(9,000 \mathrm{gpm})$. Therefore, the existing distribution appears to have enough capacity to support the raw water demands in the 200 East Area. Although the CFarm, A Complex, and AN, AW, and AP Farms are supplied by 12-in. looped distribution system, the following results are based on a single line evaluation for each of the respective farms. The supplies to each of the WFD System Phase 1 Tank Farms in the 200 East Area are addressed in the following paragraphs.

The projected demand for the B/BX/BY Farms is 4,240 lpm (1,120 gpm) per Table 3 . These farms are fed with one $0.15 \mathrm{~m}$ (6-in.) line that with fouling can supply $1,895 \mathrm{lpm}$ $(500 \mathrm{gpm})$ at $2.4 \mathrm{~m} / \mathrm{sec}(8 \mathrm{ft} / \mathrm{sec})$. The current raw water feed does not have enough capacity. A new header will need to be added to support the projected demand for these farms.

The projected demand for the C Farm is $1,705 \mathrm{lpm}$ (450 gpm) per Table 3. A new Air and Water Building was added to the $C$ Farm to support sluicing of tank 241-C-106. This building ties into the existing $0.3 \mathrm{~m}$ (12-in.) water distribution line. A $0.3 \mathrm{~m}$ (12-in.) line with fouling can supply over $7,570 \mathrm{lpm}(2,000 \mathrm{gpm})$ at $2.4 \mathrm{~m} / \mathrm{sec}(8 \mathrm{ft} / \mathrm{sec})$. Therefore, the current raw water feed has enough capacity. 
The A-Complex consists of the AY/AZ/A/AX Farms. The projected demand for the AComplex and AN Farm is 4,315 lpm (1,140 gpm) per Table 3. The A-Complex and AN Farm raw water will be fed from the same $0.3 \mathrm{~m}$ (12-in.) header that supplies the $C$ Farm. The remaining capacity of the system would be approximately $5,8651 \mathrm{pm}(1,550 \mathrm{gpm})$. Therefore, the current raw water feed has enough capacity.

The projected demand for the AW Farm is 3,030 lpm ( $800 \mathrm{gpm})$ per Table 3. The raw water to this farm will be fed from a new Caustic and Diluent Addition System provided by Project W-521 (see Section 6.4). This system will be fed from a $0.36 \mathrm{~m}$ (14-in.) line that with fouling can supply $11,360 \mathrm{lpm}(3,000 \mathrm{gpm})$ at $2.4 \mathrm{~m} / \mathrm{sec}(8 \mathrm{ft} / \mathrm{sec})$. However, this same line feeds the 242-A Evaporator that uses as much as $9,840 \mathrm{lpm}(2,600 \mathrm{gpm})$ during certain stages of operation. Since it is highly unlikely that these loads would be required simultaneously, the existing distribution appears to have enough capacity.

The projected demand for the AP Farm is $2,500 \mathrm{lpm}$ (660 gpm) per Table 3. The raw water to this farm will be fed from a new Caustic and Diluent Addition System provided by Project W-211 (see Section 6.4). This system will be fed from a new $0.3 \mathrm{~m}$ (12-in.) loop that will be added by Project W-519. A new $0.3 \mathrm{~m}$ (12-in.) line can supply approximately $10,410 \mathrm{lpm}(2,750 \mathrm{gpm})$ at $2.4 \mathrm{~m} / \mathrm{sec}(8 \mathrm{ft} / \mathrm{sec})$. This same $0.3 \mathrm{~m}(12-\mathrm{in}$. $)$ line feeds the Privatization Contractor that, according to Table 5, has a projected demand of $1,250 \mathrm{lpm}$ (330 gpm). Therefore, the $0.3 \mathrm{~m}$ (12-in.) line has enough capacity to support a total demand of 3,750 lpm (990 gpm).

\subsection{West Area Raw Water Distribution System}

Export water is fed to the 200 West Area in one $0.6 \mathrm{~m}$ (24-in.) line to the 282-WC Building. The Raw Water Distribution System for the 200 West Area is then fed primarily with a $0.5 \mathrm{~m}(20$-in.) raw water main. Considering fouling, this line would be more like a $0.48 \mathrm{~m}$ (19-in.) line. As shown in Table 6, the projected peak raw water demand for the 200 West Area is $27,600 \mathrm{lpm}(7,290 \mathrm{gpm})$. At a velocity of $2.4 \mathrm{~m} / \mathrm{sec}(8 \mathrm{ft} / \mathrm{sec})$, this line can supply approximately $24,605 \mathrm{lpm}(6,500 \mathrm{gpm})$. Therefore, the existing distribution system does not have enough capacity to support this peak demand. However, the estimated peak demand for safe storage is over 4,920 lpm (1,300 gpm) above the average historical water demands for the 200 West Area (see Table 1). In addition, the peak demand includes 9,465 lpm (2,500 gpm) for fire suppression. Since it is highly unlikely that these loads would be required simultaneously, the existing distribution appears to have enough capacity to support the average water demands. Although the S and SX Farms are supplied by 12-in. looped distribution system, the following results are based on a single line evaluation for each of the respective farms. The supplies to each of the WFD System Phase 1 Tank Farms in the 200 West Area are addressed in the following paragraphs.

The projected demand for the T/TX/TY Farms is 9,540 lpm (2,520 gpm) per Table 4. These farms are fed with one $0.15 \mathrm{~m}$ (6-in.) line and two $0.1 \mathrm{~m}$ (4-in.) lines. Considering fouling, a $0.15 \mathrm{~m}$ (6-in.) line and a $0.1 \mathrm{~m}$ (4-in.) line have a capacity of $1,895 \mathrm{lpm}(500 \mathrm{gpm})$ and $755 \mathrm{lpm}(200 \mathrm{gpm})$, respectively. Therefore, the total available capacity would be approximately 
3,405 lpm (900 gpm). The current raw water feed piping does not have enough capacity. A new header may need to be added to support the projected demand for these farms.

The projected demand for the S/SX/SY Farms is 3,180 lpm (840 gpm) per Table 4. The $\mathrm{S}$ and SX Farms are fed with a $0.15 \mathrm{~m}$ (6-in.) line, while a $0.36 \mathrm{~m}$ (14-in.) line is available for feeding the SY Farm. The $0.36 \mathrm{~m}$ (14-in.) line alone has a capacity of over $9,465 \mathrm{lpm}$ $(2,500 \mathrm{gpm})$ at a velocity of $2.4 \mathrm{~m} / \mathrm{sec}(8 \mathrm{ft} / \mathrm{sec})$; therefore, the current raw water piping system has enough capacity.

\subsection{Potable Water System}

Potable water is provided via a separate distribution system originating at 283 Water Treatment Facility in the 200 West Area. Raw water is provided to the treatment facility via the $0.3 \mathrm{~m}$ (12-in.) export line. Historic potable water flow requirements, taken from flow meters in the 200 East Area and West Area, are 1,600 lpm (420 gpm) and 644 lpm (170 gpm), respectively.

Discussions with engineers at the 283-W Facility indicate the current potable water demand is approximately 1,140 to $1,520 \mathrm{lpm}(300-400 \mathrm{gpm})$ for both the 200 East and 200 West Areas. The system itself is able to provide 4,940 to $6,080 \mathrm{lpm}(1,300-1,600 \mathrm{gpm})$ at $1,080 \mathrm{kPa}$ (110 psig) (Groth 1999). Typical potable water systems supply water at 390 to $490 \mathrm{kPa}$ (40$50 \mathrm{psig}$ ), but certain facilities in the 200 Areas utilize potable water for fire systems, thus, a higher pressure (110 psig) is supplied.

The WFD System Phase 1 activities will also place small increased flow demands on the existing system with the addition of three safety shower/eyewash stations at the diluent addition locations. Each safety shower and eyewash station is required to have a minimum flow capacity of $75.7 \mathrm{lpm}(20 \mathrm{gpm})$ and $1.5 \mathrm{lpm}(0.4 \mathrm{gpm})$, respectively (ANSI 1998). These flow rates are required to be substainable for a minimum of 15 minutes. Further, it is estimated that the Privatization Contractor potable water demands will be $735 \mathrm{lpm}(65 \mathrm{gpm})$ at $735 \mathrm{kPa}(75 \mathrm{psig})$ (Fort 1998). Cumulatively, these additional loads are estimated to increase the total 200 East and West potable water demand to $1,725-2,104 \mathrm{lpm}(456-556 \mathrm{gpm})$.

Additional potable water flow loads are expected as a result of the WFD System Phase 1 and Privatization Contractor requirements due to increased staffing for operations and engineering personnel. At the same time, other factors will tend to reduce the number of personnel taxing the potable water system due to the reduction of activities during Phase 1 time frame. Examples include reduction in Spent Nuclear Fuel activities, completion of B Plant decommissioning, etc. It is estimated that the net increase in personnel will be less than 20 percent, and that the total potable water used will also increase by that percentage resulting in a maximum estimated flow of 2,070 to $2,525 \mathrm{lpm}(547-667 \mathrm{gpm})$. This value is less than 50 percent of the existing system capacity. 


\subsection{Caustic and Diluent Addition System}

The bulk of projected flow demands in the DST farms result from water needs for tank dilution, transfer line heating, and line flushing. For these activities, the DST farms will receive this water from caustic/diluent systems that are supplied by raw water. The projected demands shown in Table 3 show a peak load of $2,650 \mathrm{lpm}(700 \mathrm{gpm})$ at the AW Farm's diluent system. To support a concurrent water demand of $2,650 \mathrm{lpm}(700 \mathrm{gpm})$, one $0.15 \mathrm{~m}$ (6-in.) line will be required; a $0.36 \mathrm{~m}$ (14-in.) line is being provided so water supply to the system is not an issue. However, the caustic/diluent systems are currently designed to only provide an outlet flow of $530 \mathrm{lpm}$ (140 gpm). This is not sufficient capacity to support the concurrent demands as currently scheduled and projected. The diluent system capacity should be evaluated and modified, if necessary, to accommodate projected flow needs.

Hot water flushes are often required to clear waste tank intrusive equipment and instrumentation along with pit decontamination. The hot water for these activities was typically supplied by the 284-E and 284-W Powerhouses via a water truck. With the powerhouse shut down, hot water is now provided from the 241 SY cross-site flush station. Hot water is generated using inline heaters, and is piped to water trucks for transport to the location where needed. 
RPP-5227

REVISON 0

\subsection{AIR REQUIREMENTS}

\subsection{Air Quality Requirements}

Two classifications of air are used at Tank Farms. Service air is bulk air with minimal quality requirements. Instrument air is filtered and dried and is often a subset of service air. The following sections define service and instrument airflow and quality requirements. Appendix D provides a listing of DST air requirements by farm.

\subsubsection{Service Air}

Documented process air quality requirements for the Tank Farms could not be located for process air. The only identified use for service air is to operate the ALCs located in AW, AY, and $\mathrm{AZ}$ Tank Farms. Adequate pressure and flow are the only critical air requirements associated with this type of equipment. Aftercoolers and auto-trap water separators should be provided on these systems to prevent excessive water build-up in air lines. Process air to ALCs is typically regulated to between 36 and 44 psig.

\subsubsection{Instrument Air}

Documented instrument air quality requirements for the Tank Farms could not be located. Based on the types of equipment served by these systems, air should be filtered to a maximum particle size of 3 micron at the instrument and dried to a minimum of $-40^{\circ} \mathrm{F}$ dewpoint. Oil content should not exceed $1 \mathrm{ppm}$. Instrument air pressure is typically regulated between 25 and 40 psig.

\subsection{Flow Requirements Evaluation}

\subsubsection{Historical Compressed Air Flow Data}

The compressed air needed to support tank farm associated activities is provided by permanently installed compressed air systems located at each farm. These systems are not equipped with flowmeters; therefore historical air flow data is not available.

\subsubsection{Compressed Air Use by Farm}

Instrument air is provided by compressed air systems located at each farm. Typical uses of instrument air include providing a small flow of purge air in the level monitoring equipment to reduce moisture buildup. Instrument air is also used for operating dip tube type specific gravity and level detection instrumentation. 
Service air is typically only available in farms equipped with ALCs. Even with project installed mixer pumps available, it may still be required to retain the ability to use the ALCs in 241-AZ and 241-AY due to the safety related cooling function that can be provided.

Table 8 provides a summary of the estimated peak process and instrument air requirements by farm. A breakdown of the compressed air loads in each farm is contained in Appendix D.

Table 8. Summary of Estimated Peak Process and Instrument Air Requirements.

\begin{tabular}{|c|c|c|c|c|}
\hline \multirow[b]{2}{*}{ Farm } & \multicolumn{2}{|c|}{ Peak Capacity Required (scfm) } & \multicolumn{2}{|c|}{ Required Pressure $^{2}$ (psig) } \\
\hline & Service Air & $\begin{array}{c}\text { Instrument } \\
\text { Air }\end{array}$ & Service Air & $\begin{array}{c}\text { Instrument } \\
\text { Air }^{4}\end{array}$ \\
\hline \multicolumn{5}{|l|}{200 East Area } \\
\hline AW Farm & 48 & 21 & 40 & $30-35$ \\
\hline AP Farm & N/A & 34 & N/A & $35-40$ \\
\hline AN Farm ${ }^{1}$ & N/A & 30 & N/A & $25-30$ \\
\hline AZ Farm & $180^{3}$ & 10 & 40 & $35-40$ \\
\hline AY Farm & $180^{3}$ & 7 & 40 & $35-40$ \\
\hline \multicolumn{5}{|l|}{200 West Area } \\
\hline SY Farm ${ }^{\top}$ & N/A & 1 & N/A & $30-35$ \\
\hline
\end{tabular}

Note:

1. Currently there are no requirements for service air at these farms.

2. Pressure requirements based on current pressure reducing valve set point.

3. AY and AZ Farms are supplied by the same compressed air system. Per discussions with facility engineers, it is extremely unlikely that ALCs will be operating in more than two tanks at any given time. The maximum required airlift circulator demand will be $180 \mathrm{scfm}$ for $\mathrm{AZ}$ and $\mathrm{AY}$ Farms combined.

4. Pressure ranges listed are for the instrument air headers. Pressure is further reduced to as low as 20 psig at the point of use for sensitive instrumentation. 


\subsection{CONCLUSIONS AND RECOMMENDATIONS}

The purpose of this evaluation was to document requirements and assess the capability of the raw water, potable water, and compressed air systems to satisfy these requirements during WFD Phase 1 waste activities at these facilities. In addition, this assessment was to consider demands from other facilities (e.g., the Vitrification Facility, PFP) and emergency water needs (e.g., fighting fire). Requirements were obtained from interviews with Tank Farm personnel and from extensive data review. The requirements have been summarized in Tables 5 and 6 for the projected raw water demands for the 200 East Area and 200 West Area, respectively. The requirements for compressed air for each farm are summarized in Table 8. Following are primary conclusions and recommendations resulting from this evaluation.

- The existing water distribution systems were assessed and it was determined that additional headers are likely needed to support the projected demands for supplying water to B/BY/BX Tank Farms, and T/TX/TY Tank Farms. The remaining network appears to be adequate; however, there is little margin available.

- It should be noted that network type hydraulic systems have complex flow behaviors that cannot always be evaluated by inspection (as has been done in this report) with a high degree of certainty. If the resulting capacity versus flow analysis had shown a capacity margin of 30 percent or more existing between the system capacity and required flows, no further analysis would be warranted. However, as can be seen by Table 7 and the preceding discussion, this margin is not available. Thus, it is recommended that a network hydraulic analysis supported by flow testing be performed to assure that adequate flows can be achieved during WFD System Phase 1 activities. This will greatly increase the confidence in the adequacy of the existing system; thereby reducing the risk that insufficient water flows will impact future activities.

- It should be noted that portions of the system are quite old (e.g., 50 years). It is likely that some elements of the new water distribution system will require repair or replacement before 2020 .

- Capacity modifications to the planned caustic/diluent systems appear to be needed.

- Observation of compressed air system operation and evaluation of existing loads indicate the systems are not running near full capacity. Minimal loads are to be added as a result of Projects W-211 and W-521; therefore, the compressed air systems appear to be adequately sized to support planned activities. However, the air distribution systems within the Tank Farms have historically experienced chronic leakage problems. It is uncertain if these distribution systems will provide satisfactory service throughout the duration of the WFD Phase 1 mission. 


\section{REVISON 0}

- The 200 East and West Potable Water Facility has sufficient capacity to support current Tank Farm activities, as well as anticipated loads associated with WFD Phase 1, and Privatization Contractor requirements. Potable water systems serving emergency shower/eyewash stations will need to be sized correctly to provide the required minimum flows specified in Section 6.3.

- Caustic/diluent systems provided by Projects W-211 and W-521 should include provisions for performing tank farm flushing and decontamination activities. 


\subsection{REFERENCES}

ANSI 1998, American National Standard for Emergency Eyewash and Shower Equipment, ANSI Z358.1-1998, American National Standards Institute, New York, New York.

Fort 1998, Design Requirements Document for TWRS Privatization Phase, HNF-SD-WM-DRD015, Rev. 1, Numatec Hanford Corporation, Richland, Washington.

Groth, 1999, Record of Conversation with T.L. Sweet (DynCorp), 200E and 200W Potable Water, ARES Letter No. 99RL1145, ARES Corporation, Richland, Washington.

Harper 1998, Letter, T. J. Harper (FDH) to W. A. Rutherford (RL), Contract No. DE-AC0696RL13200 - Water Plant Safety Reviews, FDH-9854235 R1 dated June 25, 1998, Fluor Daniel Hanford, Richland, Washington.

Kirkbride, et al., 1999, Tank Waste Remediation System Operation and Utilization Plan, HNFSD-WM-SP-012, Rev. 1, Numatec Hanford Corporation, Richland, Washington.

LMHC 1999, DRAFT, Level 2 Specification for Double-Shell Tank Transfer Pump System, HNF-4162, Rev. 0, Lockheed Martin Hanford Corp., Richland, Washington.

Parazin 1998, W-519 Water Balance Analysis for Raw Water System, HNF-3363, Rev. 0, dated, Numatec Hanford Corporation, Richland, Washington.

WAC 1999, Washington Administration Code, Chapter 246-290, "Group A Public Water Systems." 


\section{REVISON 0}

\subsection{Reference Drawings}

\begin{tabular}{|c|c|c|c|}
\hline Area & Drawing No. & Sheet & Rev. \\
\hline \multirow[t]{17}{*}{200 East } & $\mathrm{H}-2-36535$ & 1 & 20 \\
\hline & $\mathrm{H}-2-36535$ & 4 & 8 \\
\hline & $\mathrm{H}-2-36535$ & 7 & 4 \\
\hline & H-2-36535 & 8 & 0 \\
\hline & $\mathrm{H}-2-36535$ & 9 & 1 \\
\hline & $\mathrm{H}-2.36535$ & 10 & 4 \\
\hline & $\mathrm{H}-2-64400$ & $1-20$ & Varies \\
\hline & H- -85049 & 2 & 1 \\
\hline & $\mathrm{H}-2-829680$ & 1 & 0 \\
\hline & $\mathrm{H}-14-020301$ & $1-4$ & Varies \\
\hline & $\mathrm{H}-14-020302$ & $1-4$ & Varies \\
\hline & H-14-020303 & $1-4$ & Varies \\
\hline & H-14-020307 & $1-6$ & Varies \\
\hline & $\mathrm{H}-14-021801$ & 1 and 2 & Varies \\
\hline & $\mathrm{H}-14-021802$ & 1 and 2 & Varies \\
\hline & $\mathrm{H}-14-021803$ & 1 & 1 \\
\hline & $\mathrm{H}-14-021807$ & $1-3$ & Varies \\
\hline \multirow{10}{*}{200 West } & H-2-2469 & & \\
\hline & $\mathrm{H}-2-36536$ & 1 & 13 \\
\hline & $\mathrm{H}-2-85049$ & 13 & 2 \\
\hline & H-2-97700 & 1 & 0 \\
\hline & $\mathrm{H}-2-97701$ & 1 & 1 \\
\hline & $\mathrm{H}-2-97702$ & 1 & 0 \\
\hline & $\mathrm{H}-2-97715$ & 1 & 0 \\
\hline & $\mathrm{H}-2-97724$ & 1 & 0 \\
\hline & $\mathrm{H}-2-97727$ & 1 & 0 \\
\hline & $\mathrm{H}-14-021831$ & 1 and 2 & Varies \\
\hline
\end{tabular}


RPP-5227

REVISON 0

\subsection{PERSONNEL CONTACTED}

The following individuals were interviewed and provided input or information contained in this report.

\section{NAME}

JE Andrews

JW Bailey

KD Bare

DA Bragg

SR Briggs

JN Doeler

LA Domnoske-Rauch

TM Galioto

GN Hanson

WM Harty, Jr.

KJ Hull

J Jo

PJ McKenna

AL McPherson

DP Niebuhr

EM Nordquist

DB Parkman

TC Perry

DW Reberger

DA Rohl

TL Sweet

GR Tardiff

KA White

RS Wittman

\section{COMPANY}

CH2M Hill Hanford Group

Numatec Hanford Corporation

Fluor Daniel Northwest

CH2M Hill Hanford Group

Numatec Hanford Corporation

CH2M Hill Hanford Group

CH2M Hill Hanford Group

Waste Management Hanford

CH2M Hill Hanford Group

CH2M Hill Hanford Group

CH2M Hill Hanford Group

CH2M Hill Hanford Group

DynCorp Tri-Cities Services, Inc.

DynCorp Tri-Cities Services, Inc.

CH2M Hill Hanford Group

Numatec Hanford Corporation

$\mathrm{CH} 2 \mathrm{M}$ Hill Hanford Group

DynCorp Tri-Cities Services, Inc.

CH2M Hill Hanford Group

DynCorp Tri-Cities Services, Inc.

DynCorp Tri-Cities Services, Inc.

CH2M Hill Hanford Group

CH2M Hill Hanford Group

Numatec Hanford Corporation 
RPP-5227

REVISON 0

Appendix A

Water Usage Histograms

A-1 


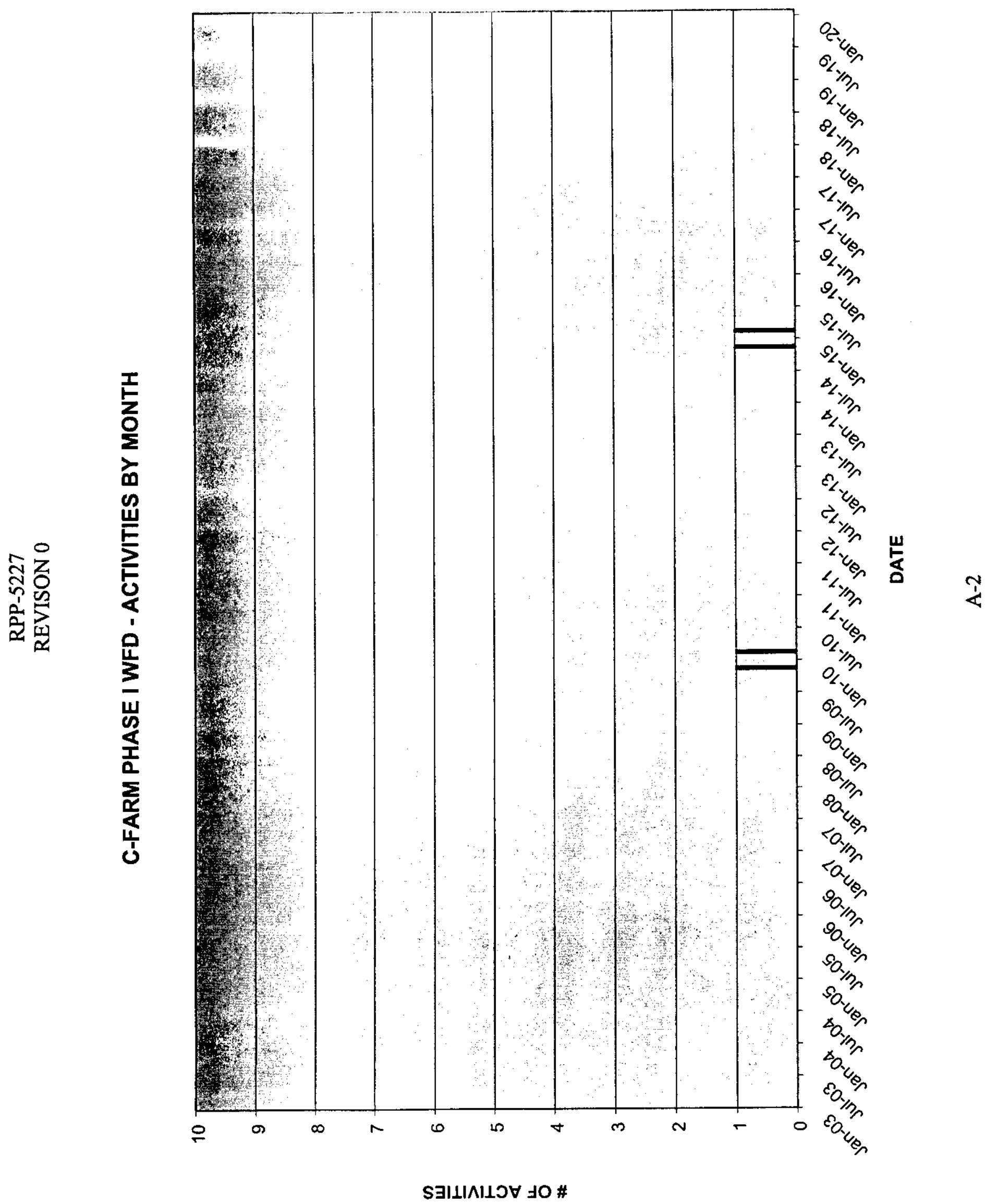




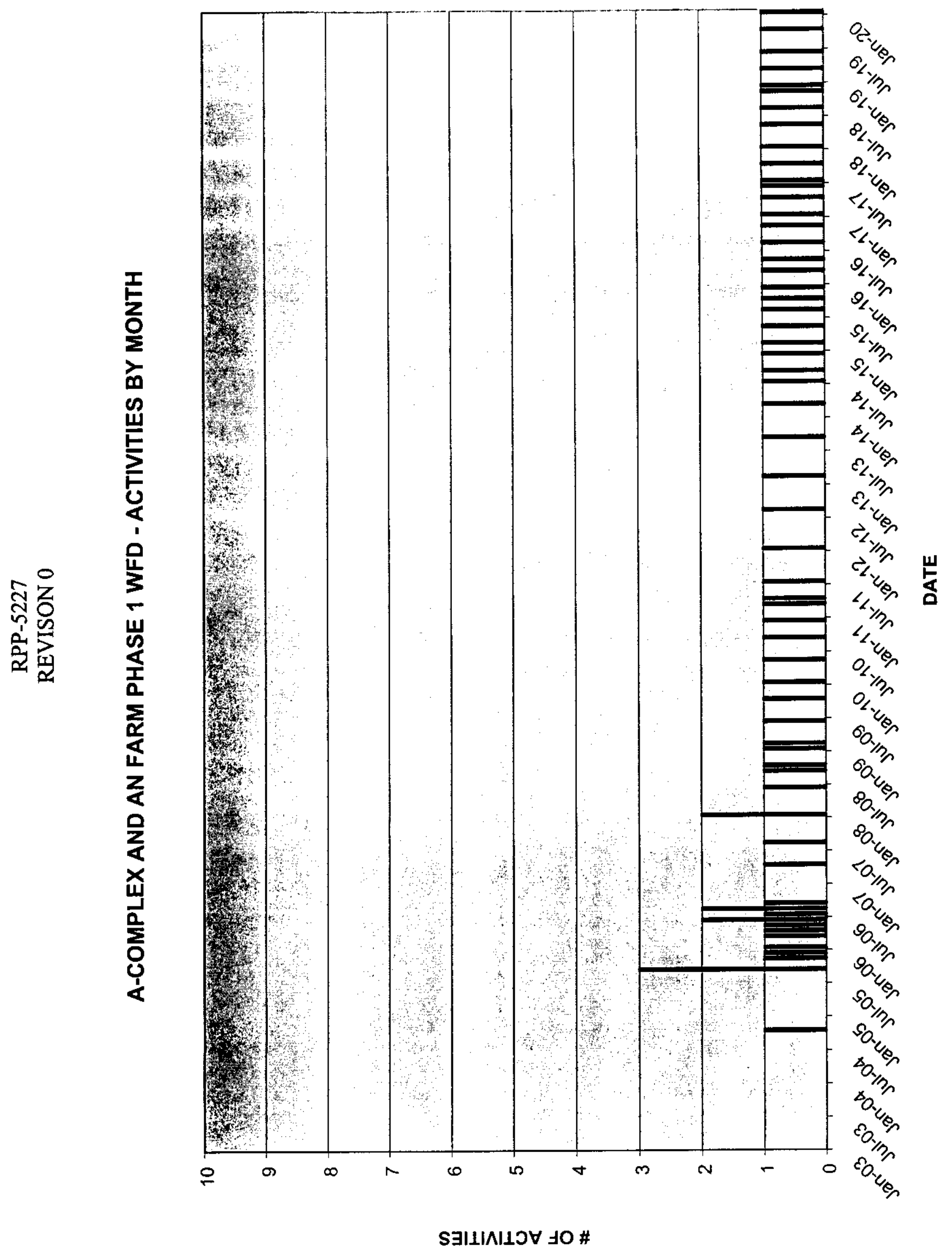

\& 


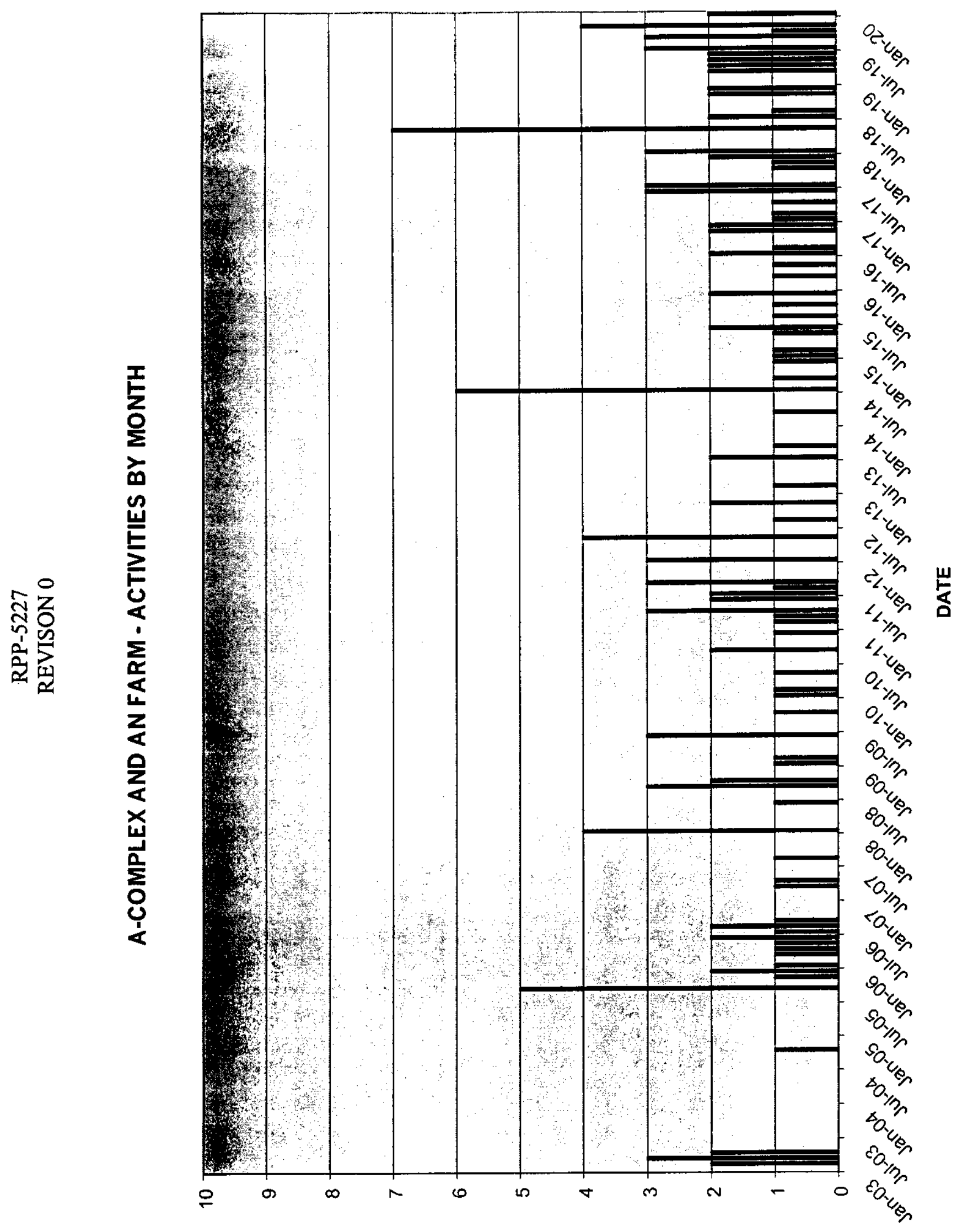




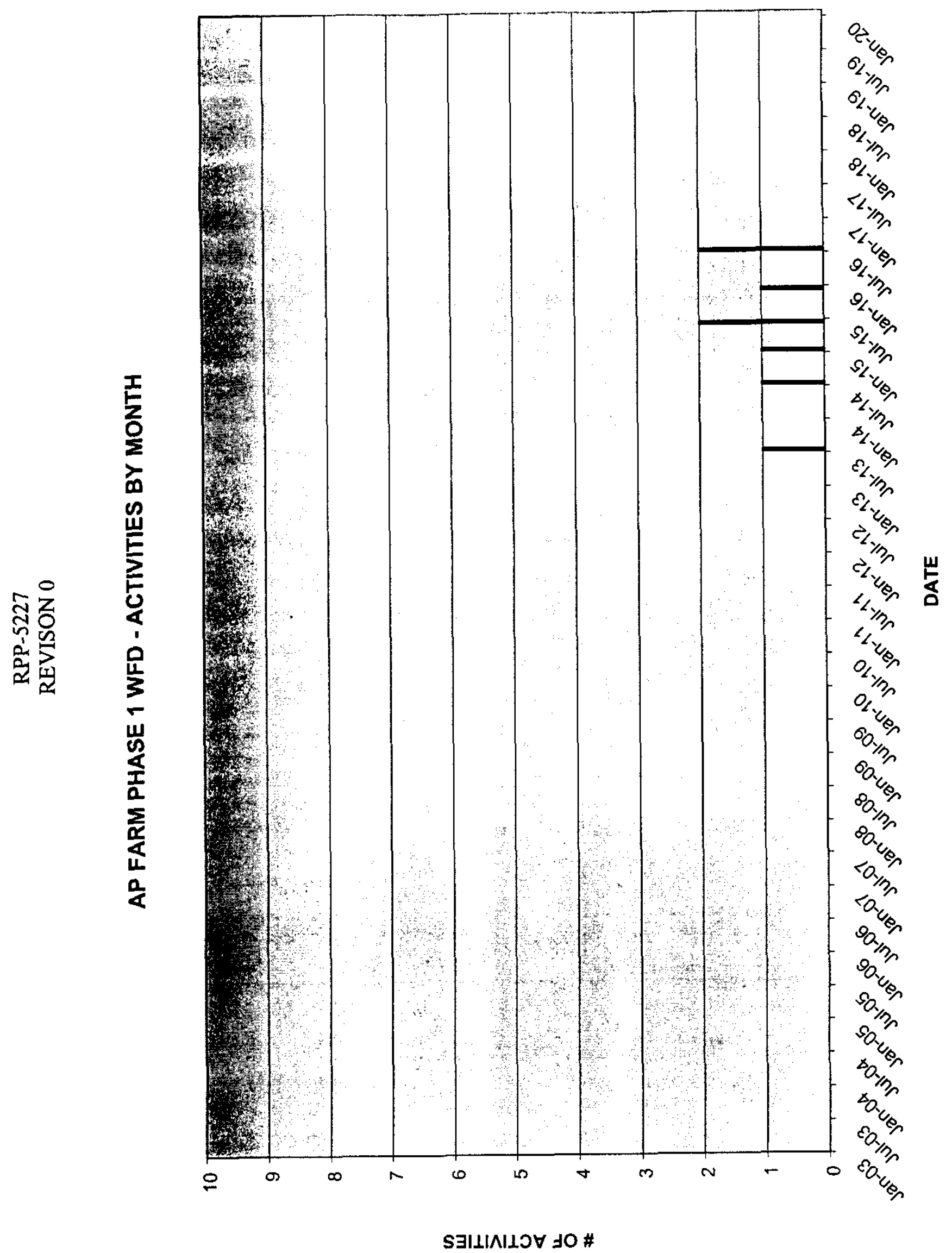




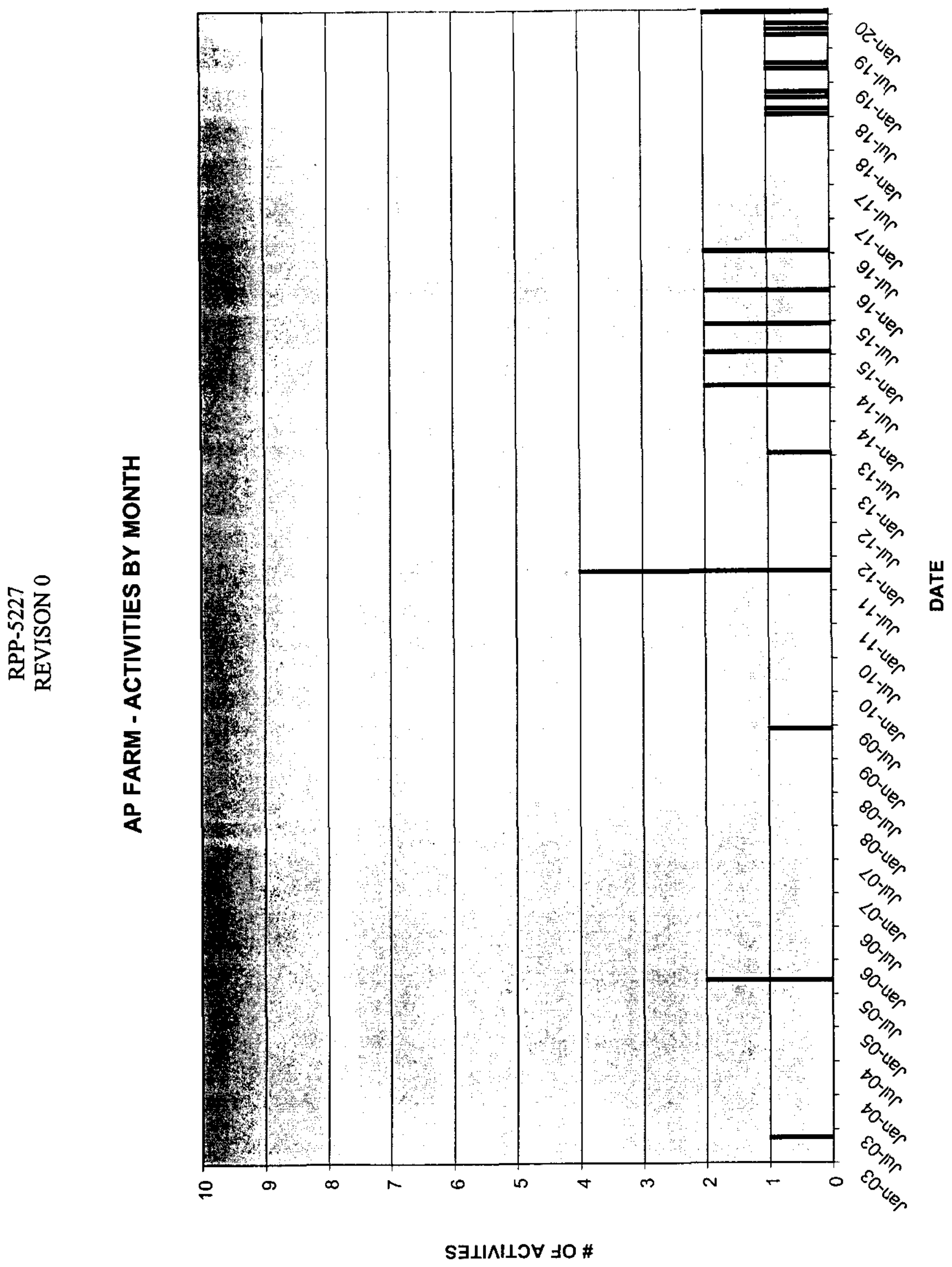




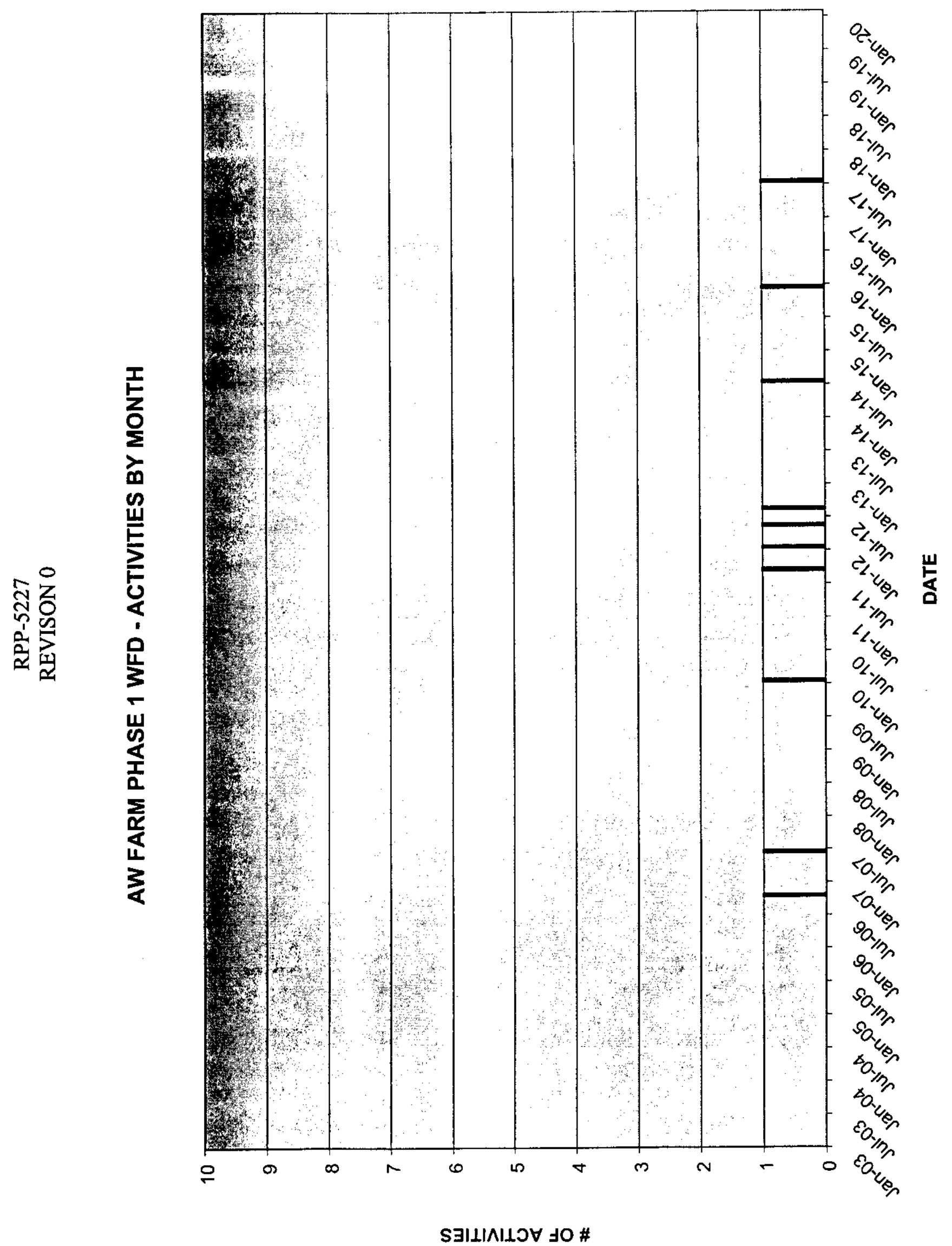




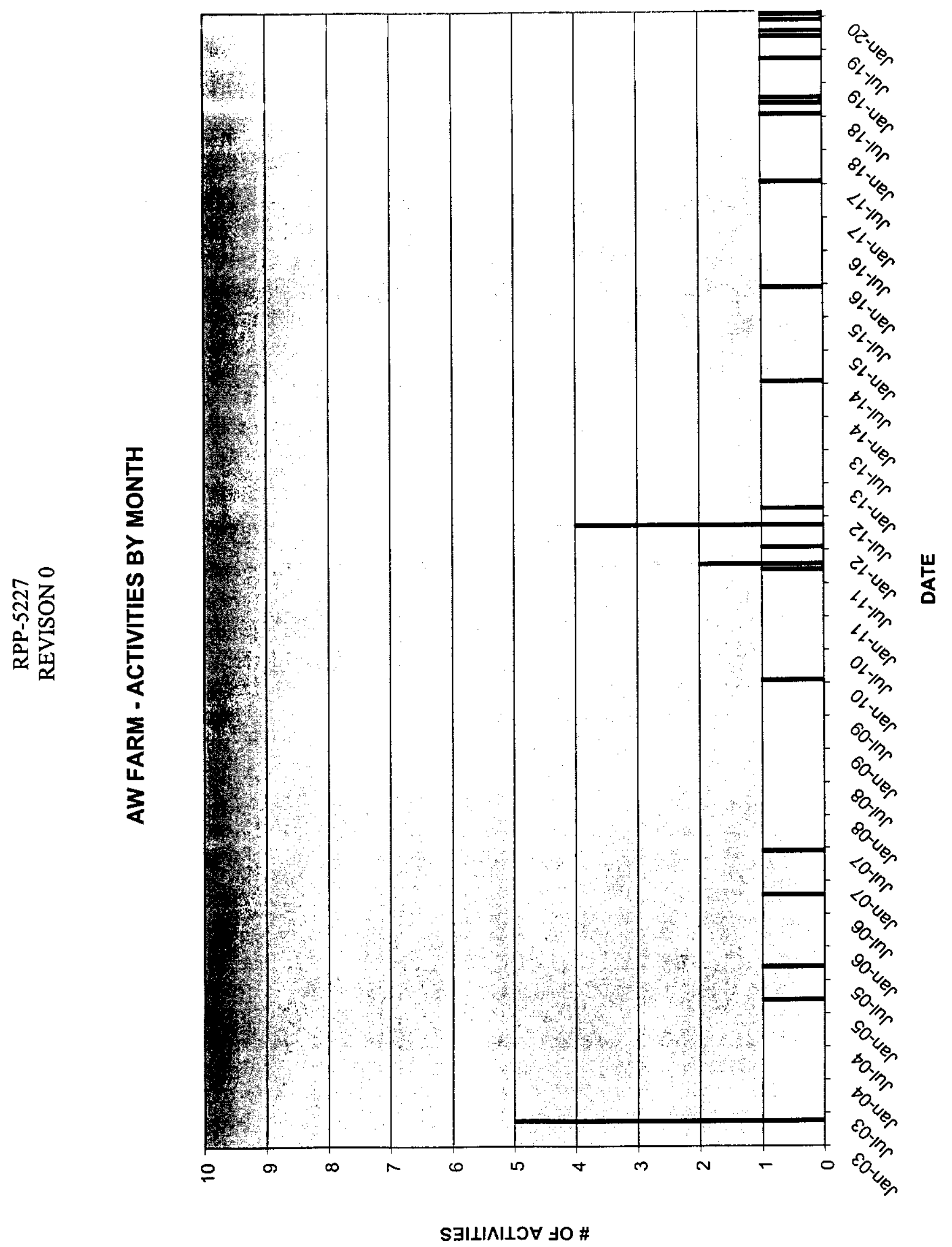

$\dot{1}$ 


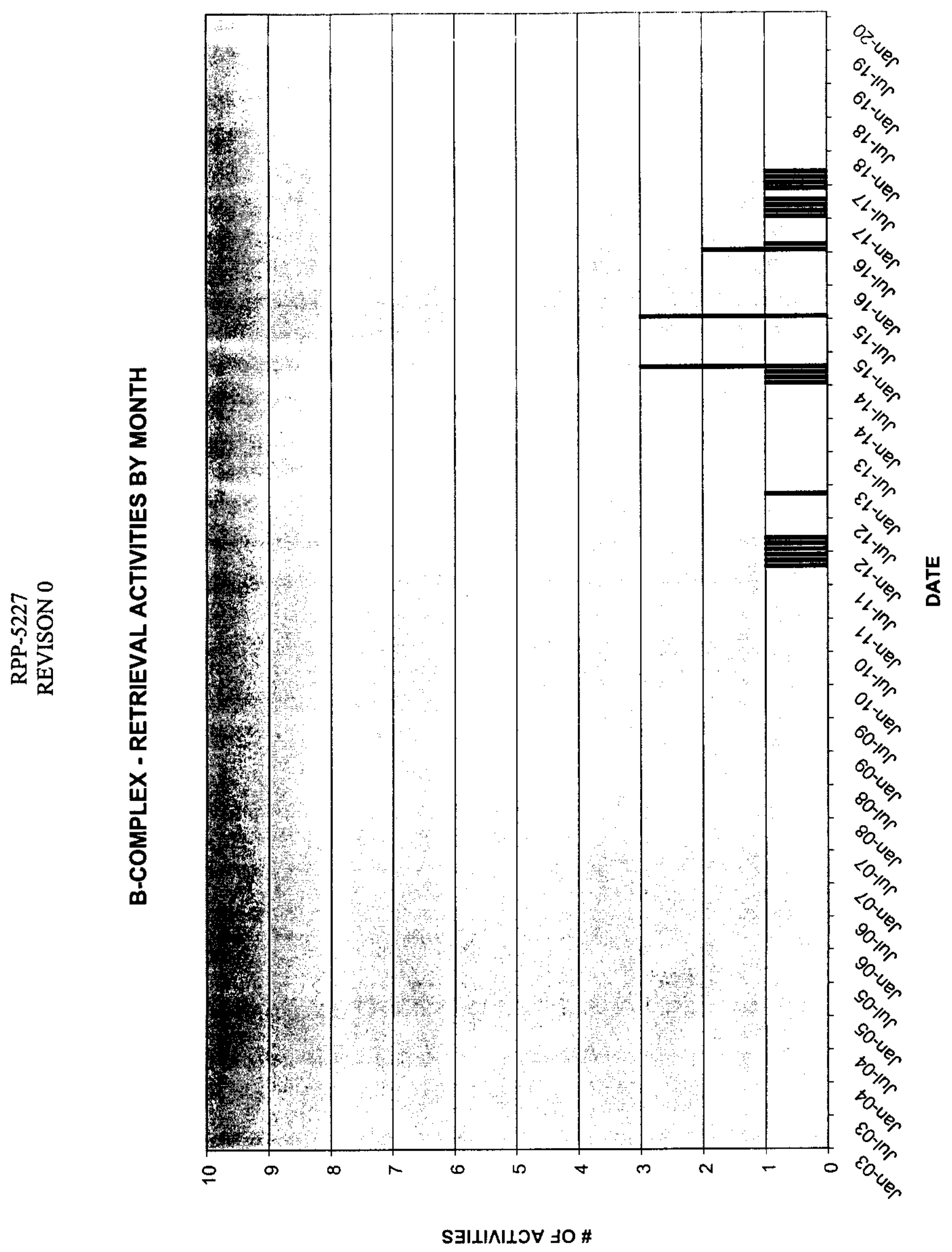




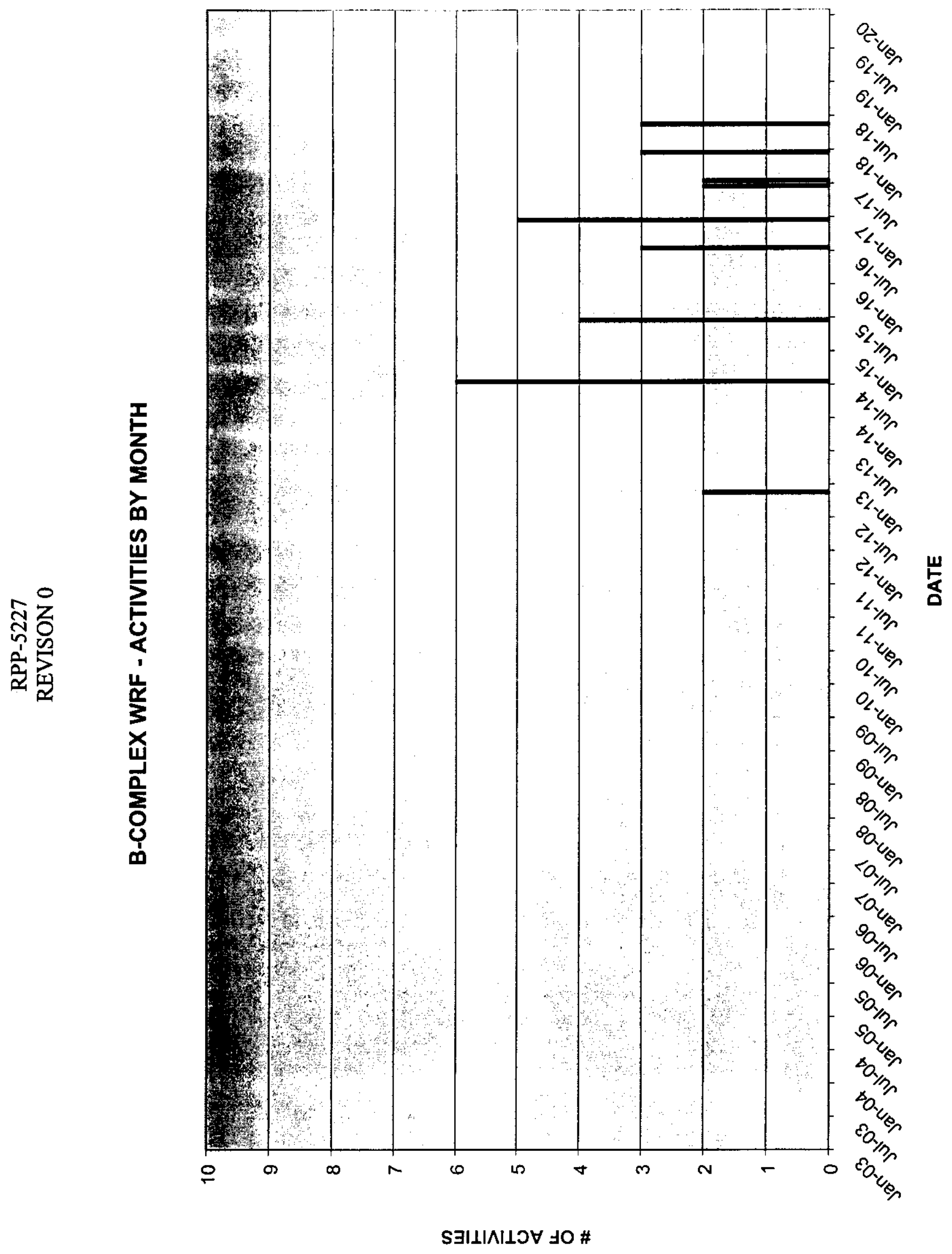




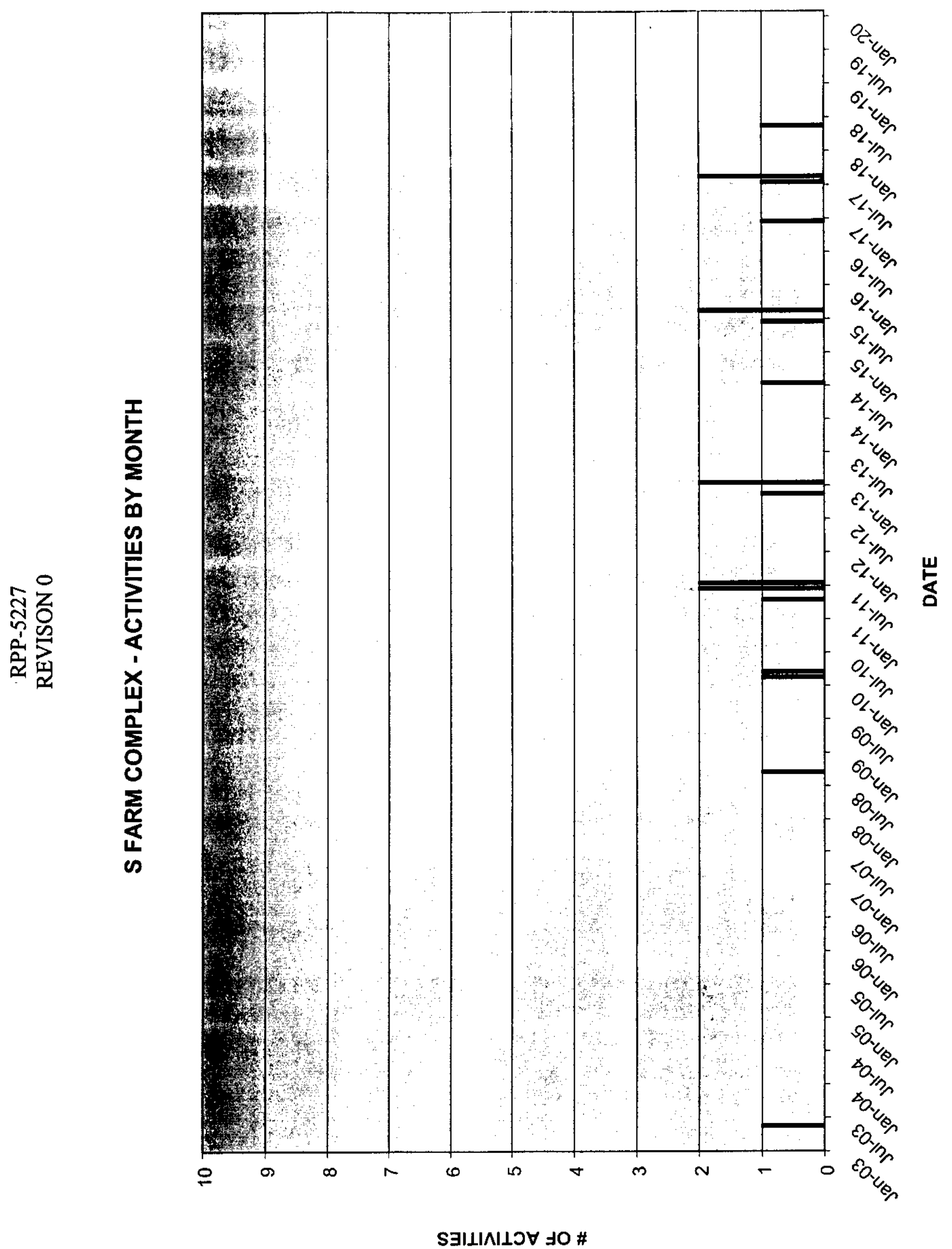

$\overline{3}$ 


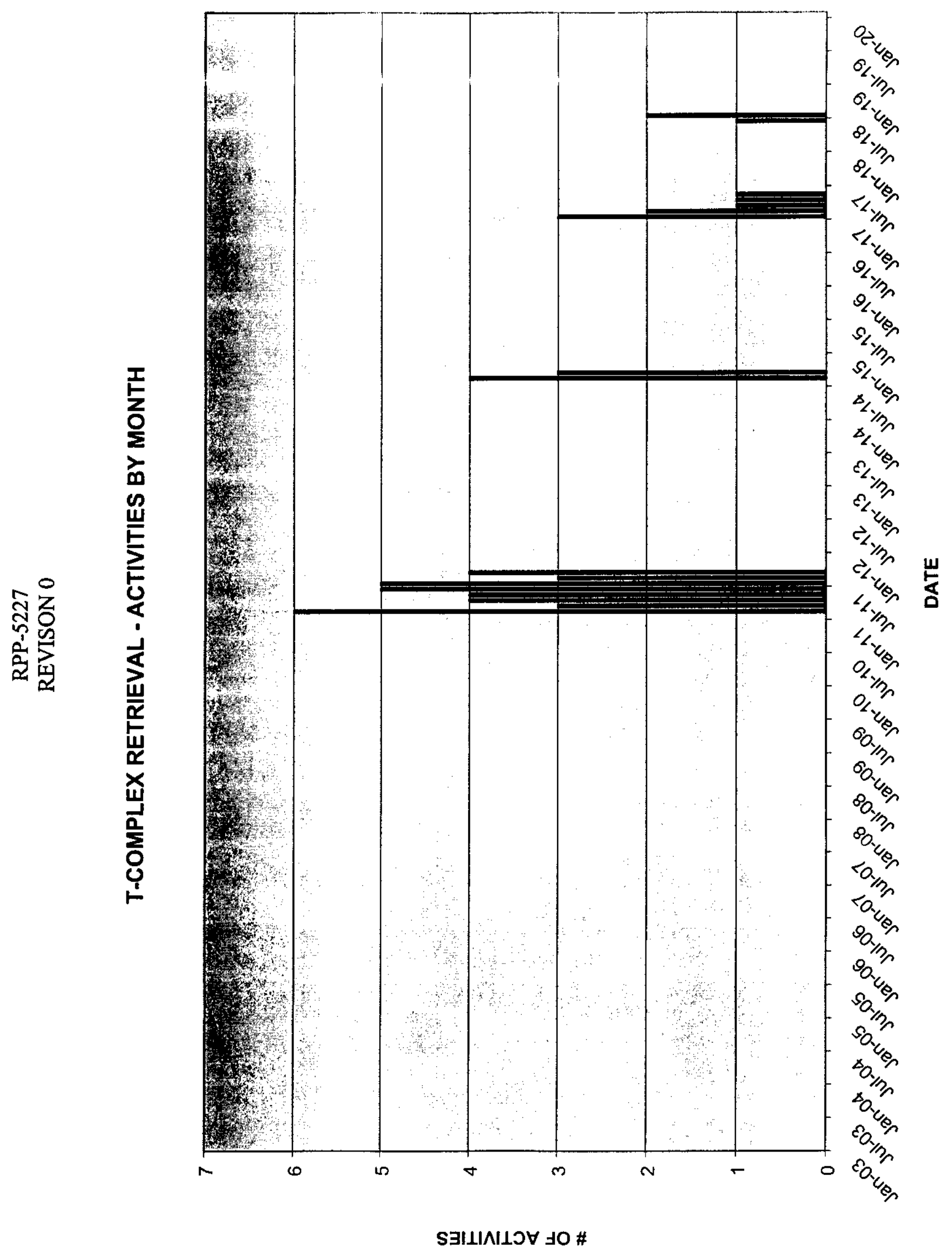




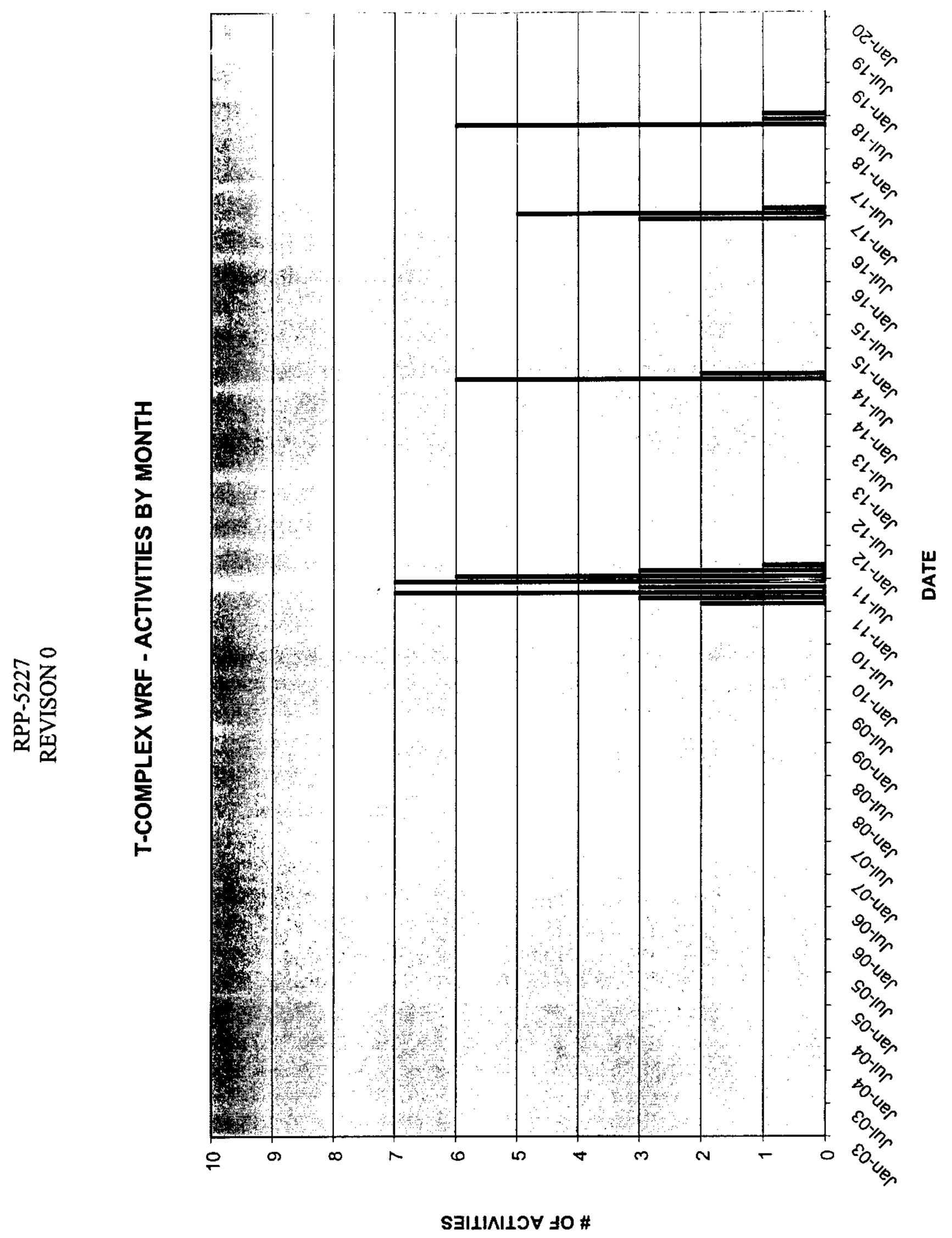


RPP-5227

REVISON 0

Appendix B

Supporting Sketches

B-1 


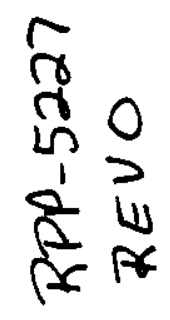

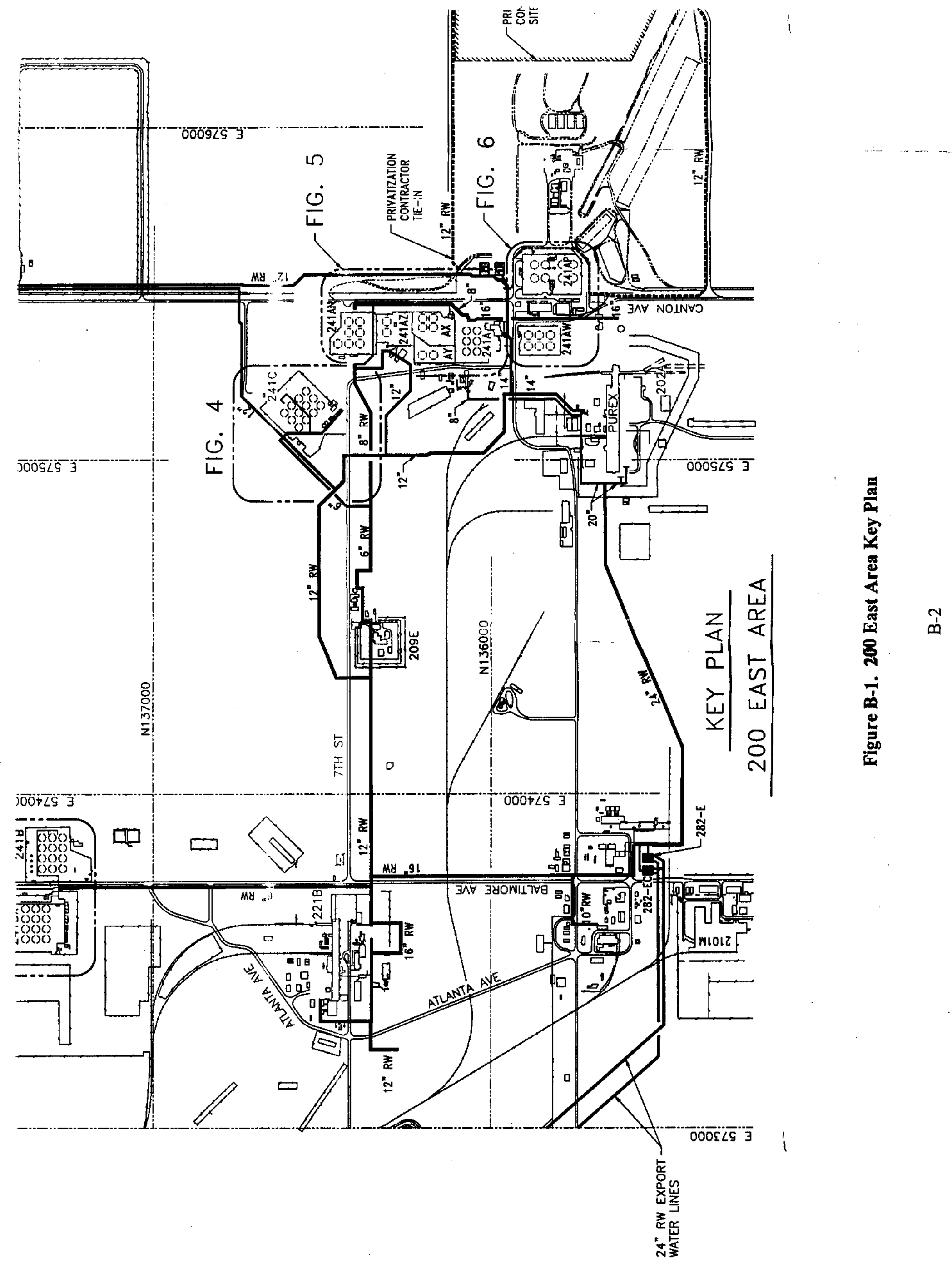




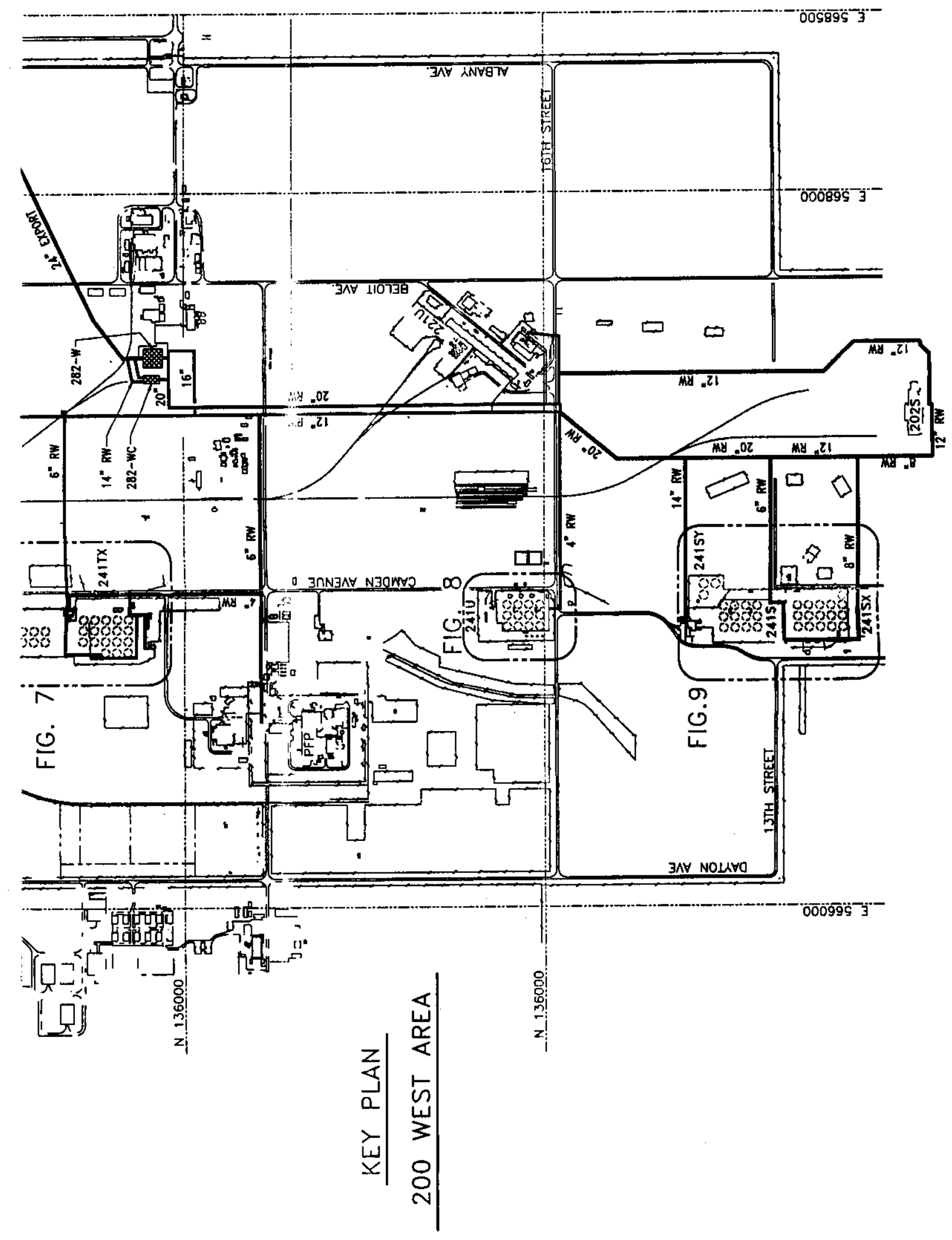


RPP-5227

REVISON 0

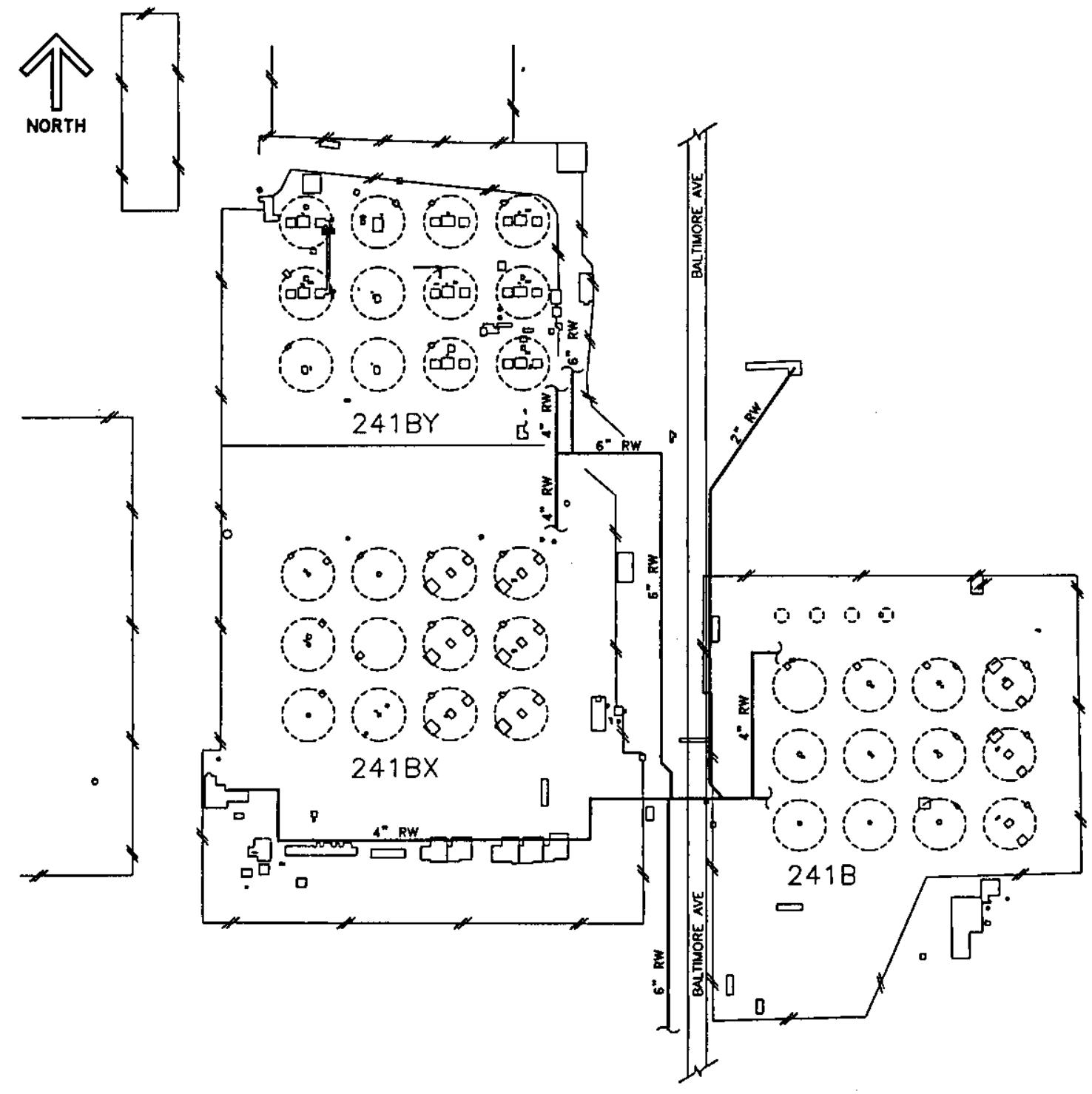

Figure B-3. B/BY/BX Complex. 
RPP-5227

REVISON 0

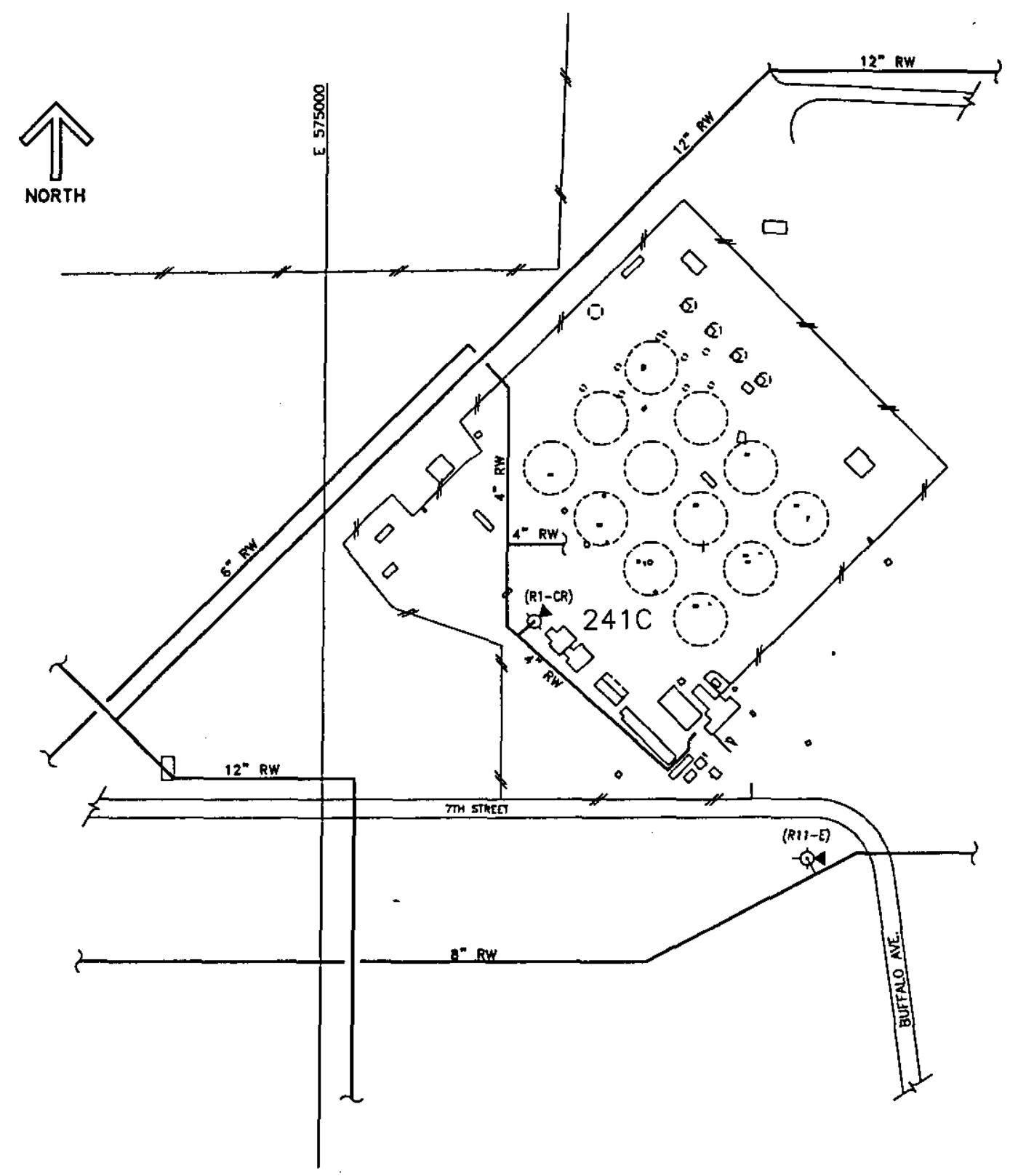

Figure B-4. C Farm.

B-5 


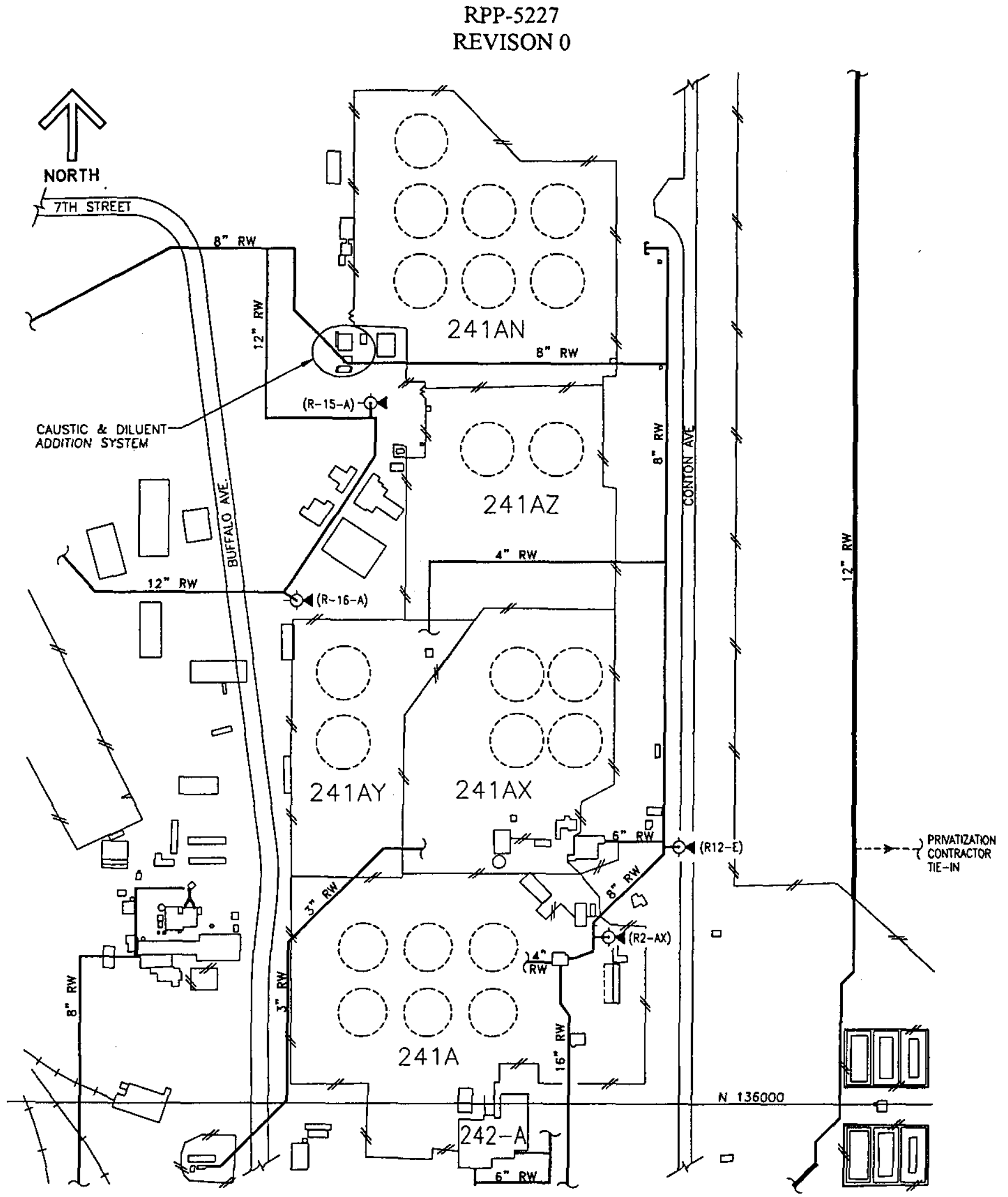

Figure B-5. A-Complex. 
REVISON 0

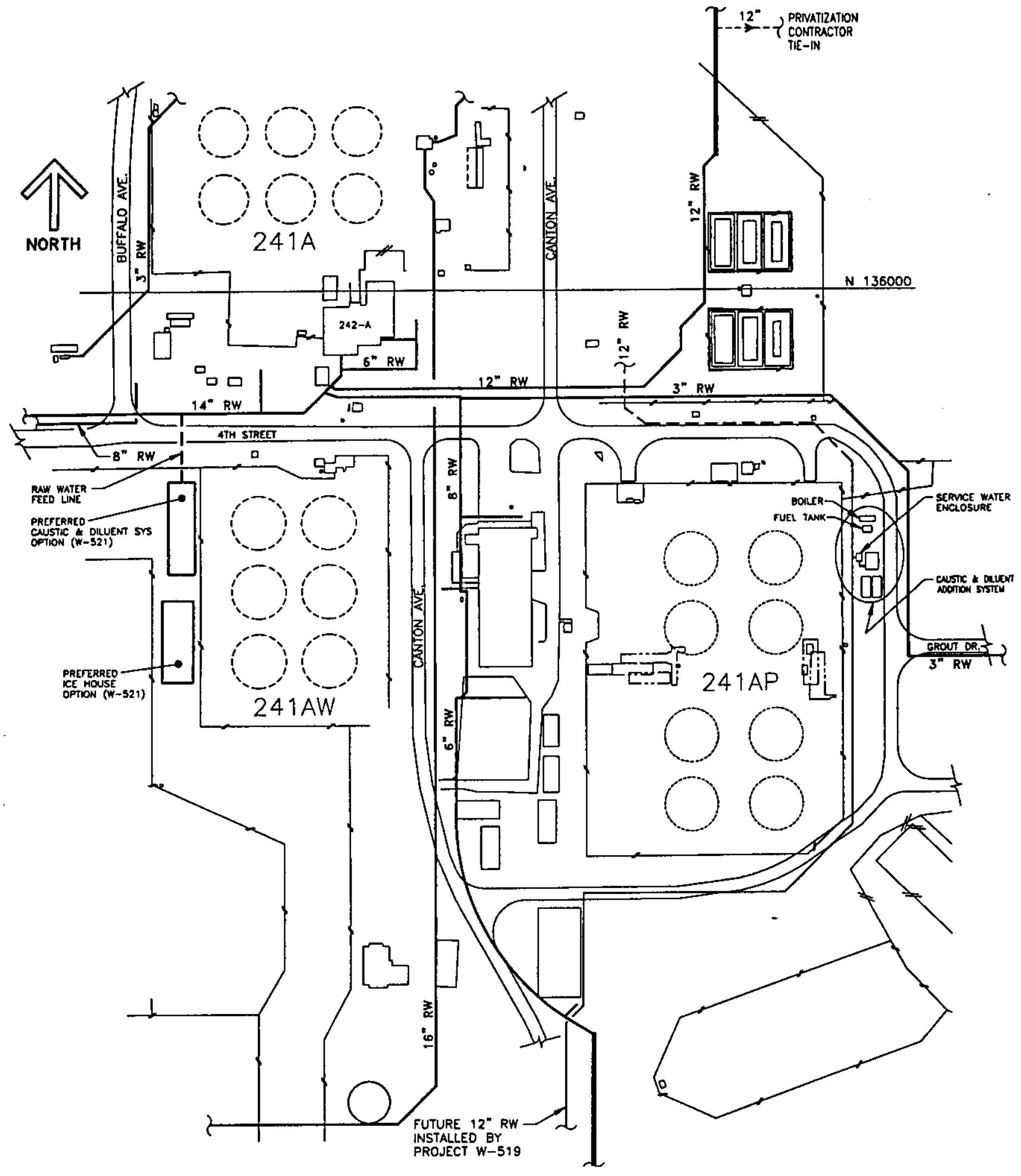

Figure B-6. AW/AP Farms. 
RPP-5227

REVISON 0

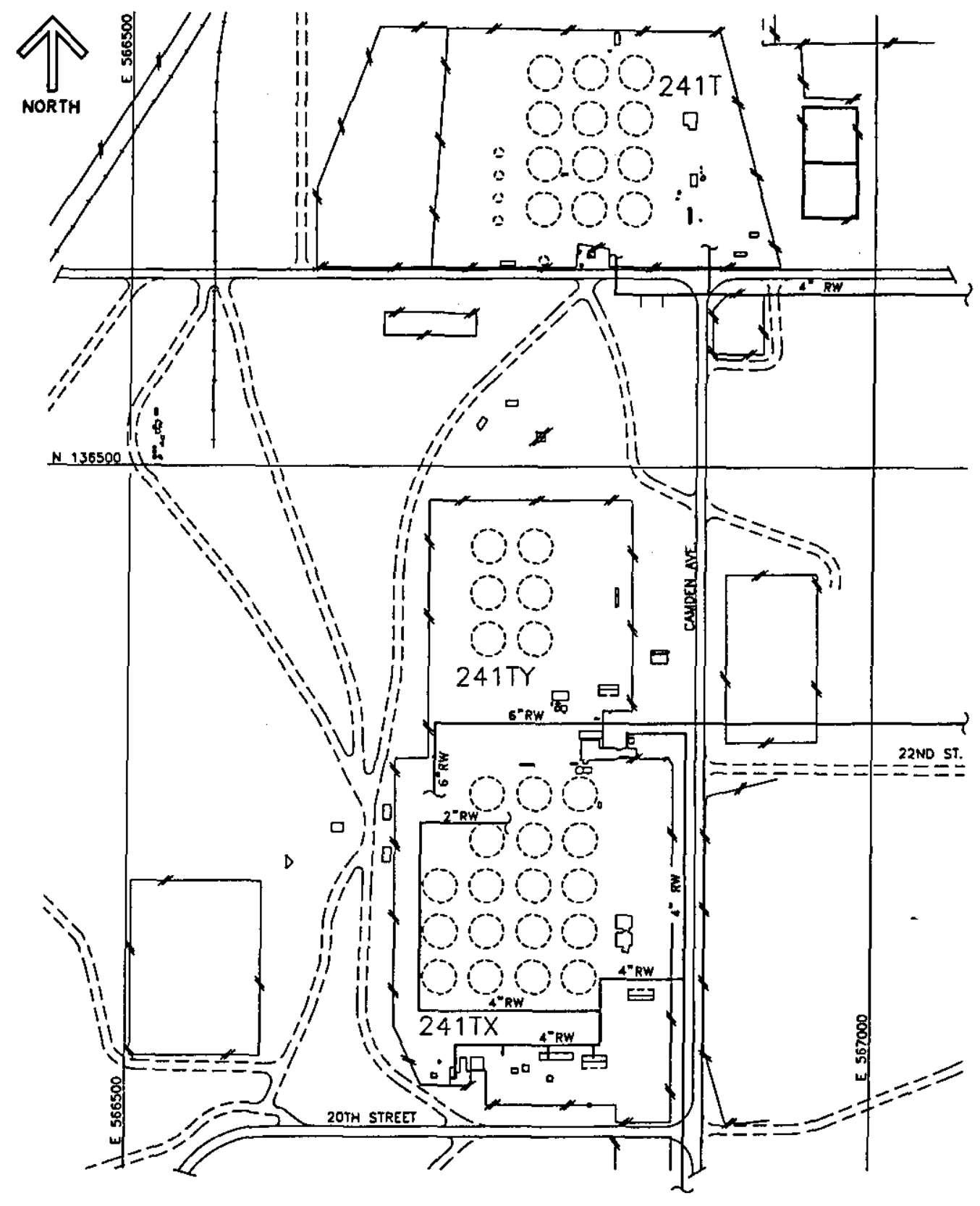

Figure B-7. T/TY/TX Farms. 


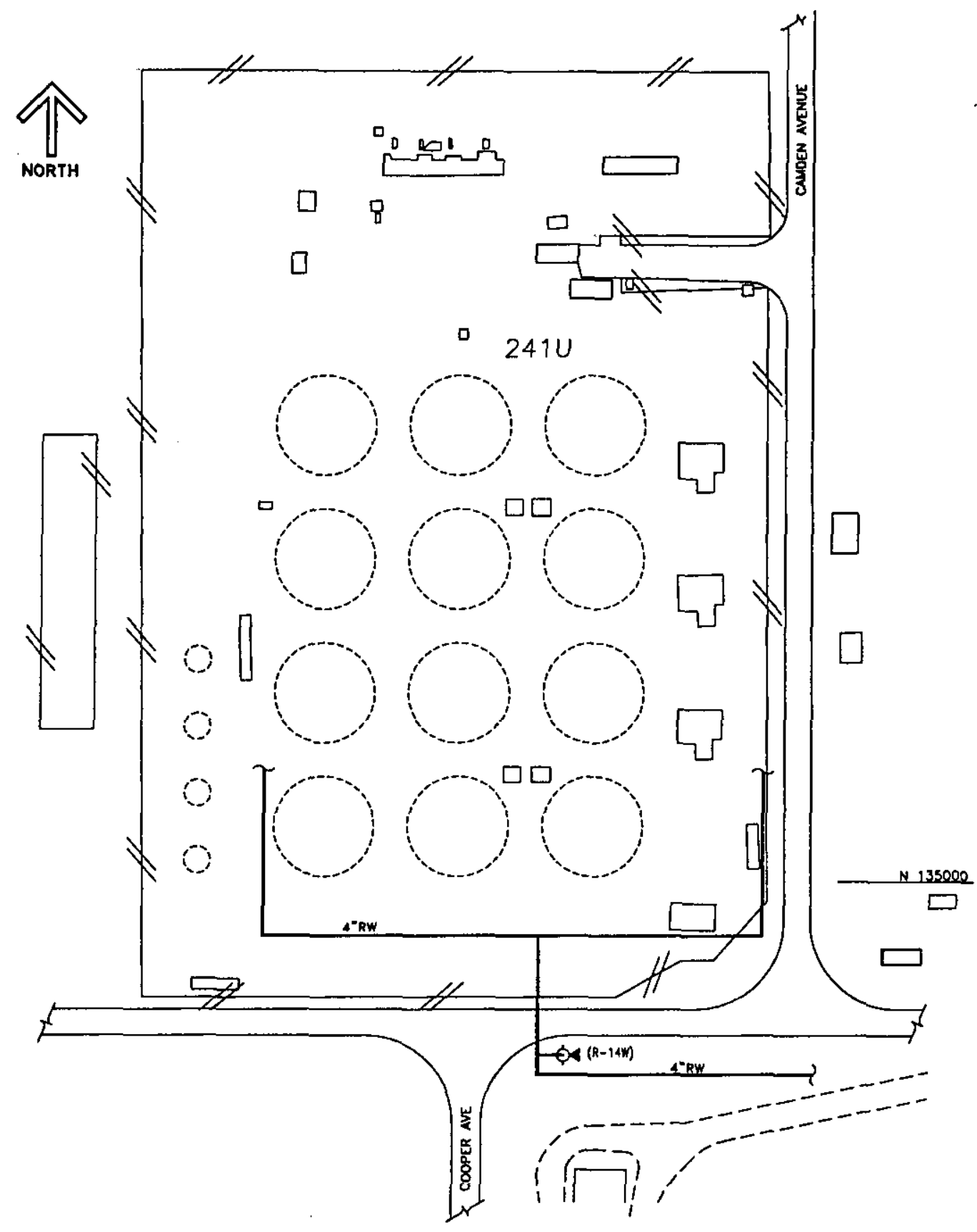

Figure B-8. U Farm. 


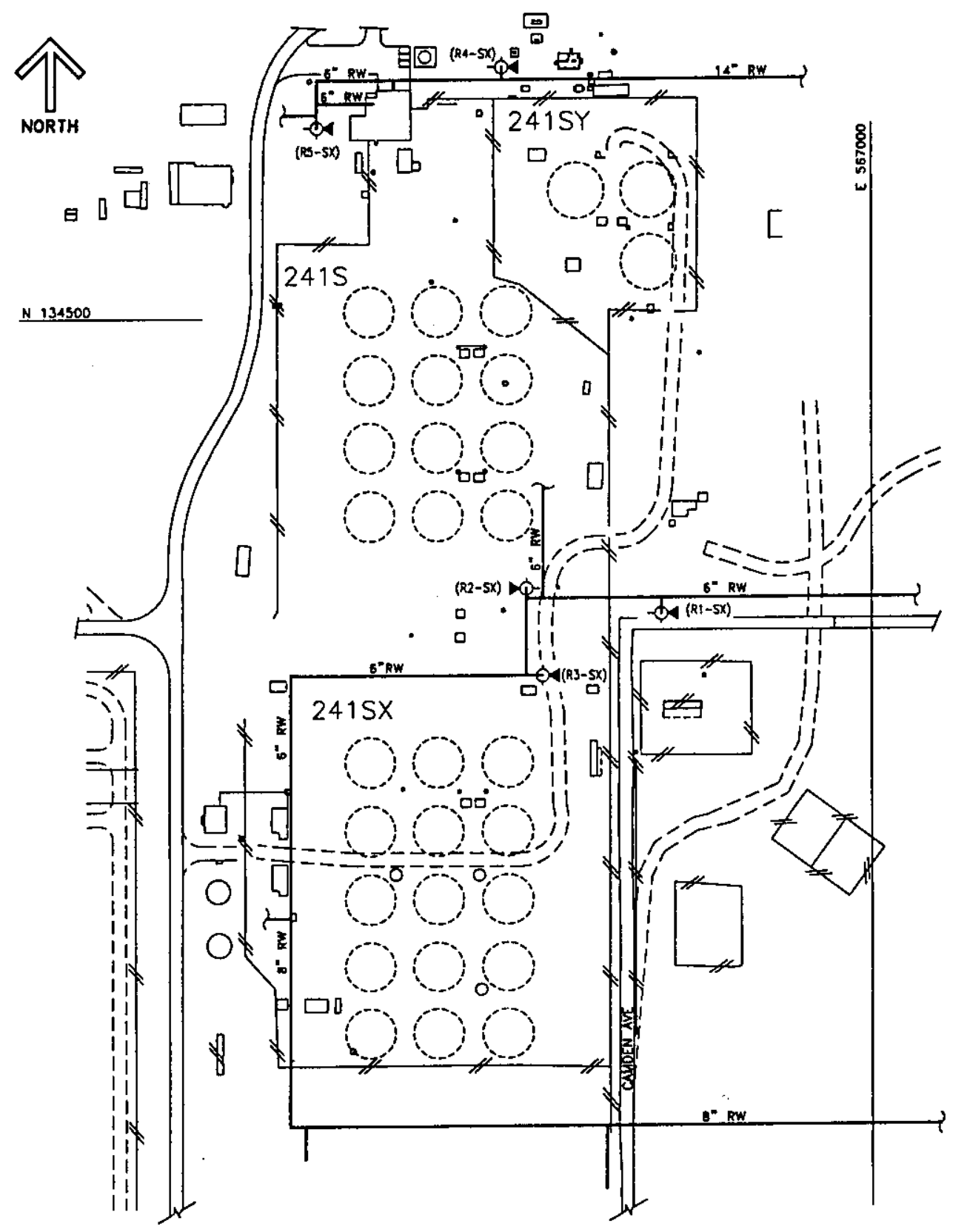

Figure B-9. SY/SX Farms. 
RPP-5227

REVISON 0

Appendix C

Potential Raw Water Uses by Farm

C-1 


\section{Raw Water Pressure and Flow Requirements}

\begin{tabular}{|c|c|c|c|c|}
\hline Component & \begin{tabular}{|c|} 
Maximum Flow \\
Rate (gpm)
\end{tabular} & $\begin{array}{l}\text { Pressure } \\
\text { (psig) }\end{array}$ & $\begin{array}{c}\text { Frequency of } \\
\text { Use }^{1}\end{array}$ & Notes \\
\hline \multicolumn{5}{|l|}{ 241-AN Farm Raw Water Usage (H-14-021801) } \\
\hline Transfer Line Flush via Valve Pit WT-AN-B (existing) & \multicolumn{4}{|c|}{$\begin{array}{l}\text { The current strategy is to use the Caustic/Diluent system installed by } \\
\text { Project W-211 and W521 to perform all transfer line flushes } \\
\text { associated with this farm. The existing flush system will not be } \\
\text { connected to the transfer routing manifolds. }\end{array}$} \\
\hline Flush for Camera Multi-Port Riser ( 3 cameras) & $3.5 /$ each & Line Pressure & Infrequent & 2,4 \\
\hline Flush for Camera View Port ( 3 cameras) & 1/each & Line Pressure & Infrequent & 2,3 \\
\hline $\begin{array}{l}28 \text { Hose Connections to Various Pits (Hose connections feed } \\
\text { permanently installed spray nozzles). Water originates from single } \\
\text { hose connection in the ANFP flush pit. }\end{array}$ & 20 & Line Pressure & Infrequent & 2,9 \\
\hline Hose Connection for Mixer Pump Column Fill ( 9 pumps) & 10/each & 80 & Infrequent & 6,8 \\
\hline $\begin{array}{l}\text { Hose Connection for Mixer Pump Cavity Flush } \\
\text { (9 pumps) }\end{array}$ & 45/each & 80 & Intermittent & 6,7 \\
\hline $\begin{array}{l}\text { Hose Connection for Mixer Pump Sparge Ring } \\
\text { (9 pumps) }\end{array}$ & 32/each & 80 & Infrequent & 6,7 \\
\hline $\begin{array}{l}\text { Upper Mechanical Seal Water Supply for Mixer Pump } \\
\text { (9 Pumps) }\end{array}$ & $\sim 0$ & 80 & Intermittent & 6,7 \\
\hline $\begin{array}{l}\text { Diluent/Flush System (waste transfer dilution, transfer pump } \\
\text { mechanical seal flush, and transfer line flush) }\end{array}$ & 140 & Line Pressure & Intermittent & 2 \\
\hline \multicolumn{5}{|l|}{ 241-AW Farm Raw Water Usage (H-14-021802) } \\
\hline Transfer Line Flush via Valve Pit WT-AW-B (existing) & 140 & Line Pressure & Intermittent & $2,5,9$ \\
\hline Transfer Line Flush via Valve Pit WT-AW-A (existing) & 140 & Line Pressure & Intermittent & $2,5,9$ \\
\hline Flush for Camera Multi-Port Riser ( 3 cameras) & 3.5/each & Line Pressure & Infrequent & 2,4 \\
\hline Flush for Camera View Port ( 3 cameras) & 1/each & Line Pressure & Infrequent & 2,3 \\
\hline Flush for Dip Tube serving PDT-101 (Tank 241-AW-102) & 20 & Line Pressure & Infrequent & 2,9 \\
\hline Service Water for Dip Tube serving PDT-101 (Tank 241-AW-102) & 20 & Line Pressure & Infrequent & 2,9 \\
\hline $\begin{array}{l}\text { Flush for Dip Tube serving PDI-101, 102, and } 103 \text { Reference Leg } \\
\text { (Tank 241-AW-102) }\end{array}$ & 20 & Line Pressure & Infrequent & 2,9 \\
\hline Flush for Dip Tube serving PDI-101 (Tank 241-AW-102) & 20 & Line Pressure & Infrequent & 2,9 \\
\hline Flush for Dip Tube serving PDI-102 (Tank 241-AW-102) & 20 & Line Pressure & Infrequent & 2,9 \\
\hline Flush for Dip Tube serving PDI-103 (Tank 241-AW-102) & 20 & Line Pressure & Infrequent & 2,9 \\
\hline Flush for Airlift Circulator WST-ALC-102 & 40 & Line Pressure & Infrequent & 2,9 \\
\hline \begin{tabular}{|l|} 
Flush for Airlift Circulator WST-ALC-103 \\
\end{tabular} & 40 & Line Pressure & Infrequent & 2,9 \\
\hline $\begin{array}{l}47 \text { Hose Connections to Various Pits (Hose connections feed } \\
\text { permanently installed spray nozzles). Water originates from single } \\
\text { hose connection in the AWFP flush pit. }\end{array}$ & 20 & Line Pressure & Infrequent & 2,9 \\
\hline Flush for 242-A Feed Pump P-007 and 3" SN-269-M25 & 140 & Line Pressure & Intermittent & 2,5 \\
\hline Hose Connection for Mixer Pump Column Fill (6 pumps) & 10/each & 80 & Infrequent & 6,8 \\
\hline $\begin{array}{l}\text { Hose Connection for Mixer Pump Cavity Flush } \\
\text { (6 pumps) }\end{array}$ & 45/each & 80 & Intermittent & 6,7 \\
\hline $\begin{array}{l}\text { Hose Connection for Mixer Pump Sparge Ring } \\
\text { ( } 6 \text { pumps) }\end{array}$ & 32/each & 80 & Infrequent & 6,7 \\
\hline $\begin{array}{l}\text { Upper Mechanical Seal Water Supply for Mixer Pump } \\
\text { (6 Pumps) }\end{array}$ & $\sim 0$ & 80 & Intermittent & 6,7 \\
\hline $\begin{array}{l}\text { Diluent/Flush System (waste transfer dilution, transfer } p \\
\text { mechanical seal flush, and transfer line flush) }\end{array}$ & 140 & Line Pressure & Intermittent & 2 \\
\hline
\end{tabular}




\section{Component}

$\begin{gathered}\text { Maximum Flow } \\ \text { Rate (gpm) }\end{gathered} \mid$

Pressure
(psig)

Frequency of
Use $^{j^{\prime}}$

Notes

\section{1-AP Farm Raw Water Usage (H-14-021803)}

Transfer Line Flush via Valve Pit 241-AP (Existing)

Hose Connection for Compressor Building 241-AP-273

19 Hose Connections to Various Pits (Hose connections feed permanently installed spray nozzles). Water originates from single hose connection in the AWFP flush pit.

Hose Connection for Mixer Pump Column Fill (2 pumps)

Hose Connection for Mixer Pump Cavity Flush

(2 pumps)

Hose Connection for Mixer Pump Sparge Ring (2 pumps)

Upper Mechanical Seal Water Supply for Mixer Pump

(2 Pumps)

Diluent/Flush System (waste transfer dilution, transfer pump

mechanical seal flush, and transfer line flush)

\begin{tabular}{|c|c|c|c|}
\hline 140 & Line Pressure & Intermittent & 2,9 \\
\hline 20 & Line Pressure & Infrequent & 2,9 \\
\hline 20 & Line Pressure & Infrequent & 2,9 \\
\hline 10/each & 80 & Infrequent & 6,8 \\
\hline $45 /$ each & 80 & Intermittent & 6,7 \\
\hline $32 /$ each & 80 & Infrequent & 6,7 \\
\hline 0 & 80 & Intermittent & 6,7 \\
\hline 140 & Line Pressure & Intermittent & 2 \\
\hline
\end{tabular}

241-AZ Farm Raw Water Usage (H-14-021807)

Hose Connection for Decontamination Sprays in Steam Condensate

Pump Pit 241-AZ-154

24 " Vent Seal Loop Fill

Decontamination Sprays in Sluice Pit 241-AZ-01C

Decontamination Sprays in Pump Pit 241-AZ-01A

Decontamination Sprays in Sluice Pit 241-AZ-01B

Decontamination Sprays in Sluice Pit 241-AZ-02C

Decontamination Sprays in Pump Pit 241-AZ-02A

Decontamination Sprays in Sluice Pit 241-AZ-02B

Flush for ALCs (22 ALCs Per Tank)

Hose Connection for Mixer Pump Cavity Flush

(WST-P-701A and WST-P-702A)

Hose Connection for Mixer Pump Column Fill (WST-P-701A and

WST-P-702A)

Hose Connection for Mixer Pump Sparge Ring (WST-P-701A and

WST-P-702A)

Upper Mechanical Seal Water Supply for Mixer Pump

(WST-P-701A and WST-P-702A)

Water to AHU-1 in 241-AZ-271

Makeup Water to Cooling Tower AZ101-EW-T-1

Makeup Water to Cooling Tower AZ102-EW-T-1

Hose Connection for Mixer Pump Column Fill (2 pumps)

Hose Connection for Mixer Pump Cavity Flush

(2 pumps)

Hose Connection for Mixer Pump Sparge Ring (2 pumps)

Upper Mechanical Seal Water Supply for Mixer Pump

(2 Pumps)

Diluent/Flush System (waste transfer dilution, transfer pump

mechanical seal flush, and transfer line flush)

\begin{tabular}{|c|c|c|c|}
\hline 50 & Line Pressure & Infrequent & 2,9 \\
\hline 5 & Line Pressure & Infrequent & 2,9 \\
\hline 50 & Line Pressure & Infrequent & 2,9 \\
\hline 50 & Line Pressure & Infrequent & 2,9 \\
\hline 50 & Line Pressure & Infrequent & 2,9 \\
\hline 50 & Line Pressure & Infrequent & 2,9 \\
\hline 50 & Line Pressure & Infrequent & 2,9 \\
\hline 50 & Line Pressure & Infrequent & 2,9 \\
\hline 5/each & Line Pressure & Infrequent & 2,9 \\
\hline 45/each & 80 & Intermittent & 11,7 \\
\hline 10/each & 80 & Infrequent & 11,8 \\
\hline $32 /$ each & 80 & Infrequent & 11,7 \\
\hline$\sim 0$ & 80 & Intermittent & 11,7 \\
\hline 1 & Line Pressure & Frequent & 2 \\
\hline 10 & Line Pressure & Continuous & 2,10 \\
\hline 10 & Line Pressure & Continuous & 2,10 \\
\hline 10/each & 80 & Infrequent & 6,8 \\
\hline 45/each & 80 & Intermittent & 6,7 \\
\hline 32/each & 80 & Infrequent & 6,7 \\
\hline$\sim 0$ & 80 & Intermittent & 6,7 \\
\hline 140 & Line Pressure & Intermittent & 2 \\
\hline 50 & Line Pressure & Infrequent & 2,9 \\
\hline 50 & Line Pressure & Infrequent & 2,9 \\
\hline 50 & Line Pressure & Infrequent & 2,9 \\
\hline 50 & Line Pressure & Infrequent & 2,9 \\
\hline
\end{tabular}

241-AY Farm Raw Water Usage (H-2-64400)

Decontamination Sprays in Sluice Pit 241-AY-02D

Decontamination Sprays in Sluice Pit 241-AY-02B

Decontamination Sprays in Sluice Pit 241-AY.02C

Decontamination Sprays in Pump Pit 241-AY-02A

\begin{tabular}{|l|l}
\hline $\mathrm{D}$ & \\
\hline $\mathrm{C}$ & \\
\hline
\end{tabular}

Line Pressure 


\begin{tabular}{|c|c|c|c|c|}
\hline Component & $\begin{array}{c}\text { Maximum Flow } \\
\text { Rate (gpm) }\end{array}$ & $\begin{array}{c}\text { Pressure } \\
\text { (psig) }\end{array}$ & $\begin{array}{c}\text { Frequency of } \\
\text { Use }\end{array}$ & Notes \\
\hline Decontamination Sprays in Sluice Pit 241-AY-02E & 50 & Line Pressure & Infrequent & 2,9 \\
\hline $\begin{array}{l}\text { Hose Connections Serving Decontamination and Water Addition } \\
\text { Sprays in Leak Detection Pit 241-AY-102A }\end{array}$ & 20 & Line Pressure & Infrequent & 2,9 \\
\hline $\begin{array}{l}\text { Hose Connection Serving Decontamination Sprays in Pump Pit } \\
241-\mathrm{AY}-01 \mathrm{~A} \text {, Sluice Pit 241-AY-01C, and Sluice Pit 241-AY-01B }\end{array}$ & 20 & Line Pressure & Infrequent & 2,9 \\
\hline Decontamination Sprays in Siuice Pit 241-AY-01D & 50 & Line Pressure & Infrequent & 2,9 \\
\hline Decontamination Sprays in Pump Pit 241-AY-01E & 50 & Line Pressure & Infrequent & 2,9 \\
\hline Flush for ALCs (22 ALCs Per Tank) & $5 /$ each & Line Pressure & Infrequent & 2,9 \\
\hline Makeup Water to Cooling Tower AY102-EW-T-1 & 10 & Line Pressure & Continuous & 2,10 \\
\hline Makeup Water to Cooling Tower AY101-EW-T-1 & 10 & Line Pressure & Continuous & 2,10 \\
\hline Hose Connection for Mixer Pump Column Fill ( 8 pumps) & $10 /$ each & 80 & Infrequent & 6,8 \\
\hline $\begin{array}{l}\text { Hose Connection for Mixer Pump Cavity Flush } \\
\text { (8 pumps) }\end{array}$ & $45 /$ each & 80 & Intermittent & 6,7 \\
\hline Hose Connection for Mixer Pump Sparge Ring ( 8 pumps) & $32 /$ each & 80 & Infrequent & 6,7 \\
\hline $\begin{array}{l}\text { Upper Mechanical Seal Water Supply for Mixer Pump } \\
\text { (8 Pumps) }\end{array}$ & $\sim 0$ & 80 & Intermittent & 6,7 \\
\hline $\begin{array}{l}\text { Diluent/Flush System (waste transfer dilution, transfer pump } \\
\text { mechanical seal flush, and transfer line flush) }\end{array}$ & 140 & Line Pressure & Intermittent & 2 \\
\hline \multicolumn{5}{|l|}{ 241-SY Farm Raw Water Usage (H-14-021831) } \\
\hline Flush Water for Valve Pit A, Nozzle L17 (Existing) & \multirow{5}{*}{\multicolumn{4}{|c|}{$\begin{array}{l}\text { The current strategy is to use the Caustic/Diluent system installed } \\
\text { by Project W-211 and W521 to perform all transfer line flushes } \\
\text { associated with this farm. The existing flush system will not be } \\
\text { connected to the transfer routing manifolds. }\end{array}$}} \\
\hline Flush Water for Valve Pit A, Nozzles L6 \& L8 (Existing) & & & & \\
\hline Flush Water for Valve Pit B, Nozzle R17 (Existing) & & & & \\
\hline Flush Water for Valve Pit B, Nozzles R6 \& R8 (Existing) & & & & \\
\hline Flush Water to Feed Pump Pit, Nozzle C (Existing) & & & & \\
\hline $\begin{array}{l}12 \text { Hose Connections to Various Pits (Hose connections feed } \\
\text { permanently installed spray nozzles). Water originates from single } \\
\text { hose connection in the SYFP flush pit. }\end{array}$ & 20 & Line Pressure & Infrequent & 2,9 \\
\hline Flush for Camera Multi-Port Riser ( 3 cameras) & 3.5/each & Line Pressure & Infrequent & 2,4 \\
\hline Flush for Camera View Port ( 3 cameras) & 1/each & Line Pressure & Infrequent & 2,3 \\
\hline Hose Connection for Mixer Pump Column Fill (6 pumps) & 10/each & 80 & Infrequent & 6,8 \\
\hline $\begin{array}{l}\text { Hose Connection for Mixer Pump Cavity Flush } \\
\text { (6 pumps) }\end{array}$ & 45/each & 80 & Intermittent & 6,7 \\
\hline Hose Connection for Mixer Pump Sparge Ring (6 pumps) & $-32 /$ each & 80 & Infrequent & 6,7 \\
\hline $\begin{array}{l}\text { Upper Mechanical Seal Water Supply for Mixer Pump } \\
\text { (6 Pumps) }\end{array}$ & $\sim 0$ & 80 & Intermittent & 6,7 \\
\hline $\begin{array}{l}\text { Diluent/Flush System (waste transfer dilution, transfer pump } \\
\text { mechanical seal flush, and transfer line flush) }\end{array}$ & 140 & Line Pressure & Intermittent & 2 \\
\hline
\end{tabular}

Notes:

1. Frequency defined as follows:

Infrequent - less than one activity per month.

Intermittent - greater than or equal to one activity per month but less than once per week.

Frequent - greater than or equal to one activity per week.

2. There is no pressure requirement for this activity. Operational experience indicates existing raw water pressure is adequate. Normal static operating pressure for the raw water system is $80-110$ psig.

3. "Intermittent" to "Frequent" view port flushing may be require in tanks where sluicing activities are performed.

4. Multiport flushing only required during camera removal for maintenance or disposal.

5. The flow rate for transfer line flushing is based on the minimum flowrate required for performing transfers. Operational history indicates the maximum flow rate through the existing system is less than $60 \mathrm{gpm}$. The existing flush system will be an alternate to the project installed Caustic/Diluent system, which will be the primary method for flushing transfer lines. The Caustic/Diluent systems for each farm/complex are supplied 
RPP-5227

\section{REVISON 0}

directly from the Central Plateau Distribution System and will not impact the raw water capacity available to each farm.

6. Raw water is supplied to the mixer pumps via the project installed Service Water system. The Service Water systems for each farm/complex are supplied directly from the Central Plateau Distribution System and will not impact the raw water capacity available to each farm. Pressure is reduced to $80 \mathrm{psig}$ within the Service Water System.

7. Flow rates based on information provided in the associated vendor manual.

8. No flow requirement listed in vendor manual. $10 \mathrm{gpm}$ based on the ability to fill the 500 gal capacity pump column in less than 1 hour.

9. There is no flow requirement for this activity. Values given are approximates based on the supply line size.

10. Cooling towers are operated in a "feed and bleed" mode where water is continuously added and drained from the catch pans. Average flow is approximately $5 \mathrm{gpm}$ per tower but may approach $10 \mathrm{gpm}$ during peak demand. All four cooling towers in 241-AZ and 241-AY may operate simultaneously.

11. Mixer pumps WST-P-701A and WST-P-702A were installed in 241-AZ-101 by Project W-151. Filtered raw water is supplied by the existing 241-AZ Tank Farm distribution system. 
RPP-5227

REVISON 0

Appendix D

Potential Compressed Air Uses by Farm

D-1 


\section{Compressed Air Pressure and Flow Requirements}

\begin{tabular}{|c|c|c|c|c|}
\hline Component & $\begin{array}{c}\text { Maximum } \\
\text { Flow Rate } \\
\text { (scfh) }\end{array}$ & Pressure (psig) & $\begin{array}{l}\text { Frequency } \\
\text { of Use }^{1}\end{array}$ & Notes \\
\hline \multicolumn{5}{|l|}{ 241-AN Farm Air Use (H-14-020301) } \\
\hline \multicolumn{5}{|l|}{ Instrument Air } \\
\hline Tank Video Purge & 10 & $25-30$ & See Note & 2 \\
\hline $\begin{array}{l}\text { Dip Tube Purge Air for Specific Gravity, Weight Factor, Pressure } \\
\text { Instrumentation (63 Lines @ 1.5 scfh each) }\end{array}$ & 95 & $25-30$ & Continuous & 3,4 \\
\hline $\begin{array}{l}\text { Purge Air for Liquid Level Detection Equipment (FICs and } \\
\text { Manual Tape)(31 Instruments @ } 50 \text { scfh each) }\end{array}$ & 1,550 & $25-30$ & Continuous & 3,4 \\
\hline \multicolumn{5}{|l|}{ 241-AW Farm Air Use (H-14-020302) } \\
\hline \multicolumn{5}{|l|}{ Service Air } \\
\hline Service Air for Airlift Circulator WST-ALC- 102 & 780 & 40 & Intermittent & 3,4 \\
\hline Service Air for Airlift Circulator WST-ALC-103 & 2,100 & 40 & Intermittent & 3,4 \\
\hline \multicolumn{5}{|l|}{ Instrument Air } \\
\hline $\begin{array}{l}\text { Dip Tube Purge Air for Specific Gravity, Weight Factor, Pressure } \\
\text { Instrumentation (48 Lines @ } 1.5 \mathrm{scfh} \text { each) }\end{array}$ & 72 & $30-35$ & Continuous & 3,4 \\
\hline $\begin{array}{l}\text { Purge Air for Liquid Level Detection Equipment (FICs and } \\
\text { Manual Tape) (24 Instruments @ } 50 \mathrm{scfh} \text { each) }\end{array}$ & 1,200 & $30-35$ & Continuous & 3,4 \\
\hline \multicolumn{5}{|l|}{ 241-AP Farm Air Use (H-14-020303) } \\
\hline \multicolumn{5}{|l|}{ Instrument Air } \\
\hline $\begin{array}{l}\text { Dip Tube Purge Air for Specific Gravity, Weight Factor, Pressure } \\
\text { Instrumentation (14 Lines @ } 1.5 \text { scfh each) }\end{array}$ & 21 & $35-40$ & Continuous & 3,4 \\
\hline $\begin{array}{l}\text { Purge Air for Liquid Level Detection Equipment (FICs and } \\
\text { Manual Tape) (40 Instruments @ } 50 \mathrm{scfh} \text { each) }\end{array}$ & 2,000 & $35-40$ & Continuous & 3,4 \\
\hline \multicolumn{5}{|l|}{ 241-AZ Farm Air Use (H-14-020307) } \\
\hline \multicolumn{5}{|l|}{ Service Air } \\
\hline ALCs for 101-AZ (22@ 4 scfm each) & 5,280 & $35-40$ & Infrequent & 3,4 \\
\hline ALCs for 102-AZ (22@4 scfm each) & 5,280 & $35-40$ & Infrequent & 3,4 \\
\hline Recirculation Fan Shaft Seals (2@ $@<5$ scfh each) & $<10$ & 5 & Continuous & 5 \\
\hline \multicolumn{5}{|l|}{ Instrument Air } \\
\hline $\begin{array}{l}\text { Dip Tube Purge Air for Specific Gravity, Weight Factor, Pressure } \\
\text { Instrumentation (21 Lines @ } 1.5 \text { scfh each) }\end{array}$ & 32 & $35-40$ & Continuous & 3,4 \\
\hline $\begin{array}{l}\text { Purge Air for Liquid Level Detection Equipment (FICs and } \\
\text { Manual Tape) (11 Instruments @ } 50 \text { scfh each) }\end{array}$ & 550 & $35-40$ & Continuous & 3,4 \\
\hline \multicolumn{5}{|l|}{ 241-AY Farm Air Use (H-2-64400) } \\
\hline \multicolumn{5}{|l|}{ Service Air } \\
\hline ALCs for 101-AZ (22@ 4 scfm each) & 5,280 & $35-40$ & Infrequent & 3,4 \\
\hline ALCs for 102-AZ (22@4 scfm each) & 5,280 & $35-40$ & Infrequent & 3,4 \\
\hline Recirculation Fan Shaft Seals (2@ $<5$ scfh each) & $<10$ & 5 & Continuous & 5 \\
\hline
\end{tabular}


RPP-5227

REVISON 0

\begin{tabular}{|c|c|c|c|c|}
\hline Component & $\begin{array}{l}\text { Maximum } \\
\text { Flow Rate } \\
\text { (sclh) }\end{array}$ & Pressure (psig) & $\begin{array}{l}\text { Frequency } \\
\text { of Use }\end{array}$ & Notes \\
\hline \multicolumn{5}{|l|}{ Instrument Air } \\
\hline $\begin{array}{l}\text { Dip Tube Purge Air for Specific Gravity, Weight Factor, Pressure } \\
\text { Instrumentation ( } 23 \text { Lines @ } 1.5 \text { scfh each) }\end{array}$ & 35 & $35-40$ & Continuous & 3,4 \\
\hline $\begin{array}{l}\text { Purge Air for Liquid Level Detection Equipment (FICs and } \\
\text { Manual Tape) ( } 7 \text { Instruments @ } 50 \text { scfh each) }\end{array}$ & 350 & $35-40$ & Continuous & 3,4 \\
\hline \multicolumn{5}{|l|}{ 241-SY Farm Air Use } \\
\hline \multicolumn{5}{|l|}{ Instrument Air } \\
\hline $\begin{array}{l}\text { Dip Tube Purge Air for Specific Gravity, Weight Factor, Pressure } \\
\text { Instrumentation, and Encasement Leak Detection (36 Lines @ } \\
1.5 \text { scfh each) }\end{array}$ & 54 & $30-35$ & Continuous & 3,4 \\
\hline
\end{tabular}

Notes:

1. Frequency defined as follows:

Infrequent - less than one activity per month.

Intermittent - greater than or equal to one activity per month but less than once per week.

Frequent - greater than or equal to one activity per week.

2. Per cognizant engineer, air is isolated to camera and camera is currently shutdown due to lack of maintenance.

3. Flow Rate obtained from applicable operating procedure.

4. Pressure based on set point of Pressure Regulating Valve (PRV) located immediately after air dryer. Pressure reduced further at point of use in many cases.

5. Pressure based on set point of Pressure Regulating Valve (PRV) located in supply line to air seal. 


\section{DISTRIBUTION SHEET}

To

Distribution

Project TitleNWork Order

Waste Feed Delivery Raw Water, Potable, Water, and Compressed Air Capacity Evaluation

\begin{tabular}{|l|l|}
\hline \multicolumn{1}{|c|}{ Name } & \\
\hline H.R. Hopkins & \\
\hline A.H. Friberg . & \\
\hline D.G. Baide & \\
\hline D.A. Bragg & \\
\hline R.E. Larson & \\
\hline C.B. Bryan & \\
\hline S.R. Briggs & \\
\hline J.E. Van Beek & \\
\hline R.R. Bevins & \\
\hline J.W. Lentsch & \\
\hline K.A. White & \\
\hline G.W. McLellan & \\
\hline G.C. DeWeese & \\
\hline R.S. Popielarczyk & \\
\hline C. Defigh-Price & \\
\hline N.W. Kirch & \\
\hline T.H. May (4) & \\
\hline G.D. Roosendaal & \\
\hline T.L. Sweet & \\
\hline G.P Duncan & \\
\hline R.A. Dodd & \\
\hline J.A. Ranschau & \\
\hline S.K. Alexander & \\
\hline P.L. Smith & \\
\hline R.M. Pierson & \\
\hline D.M. Hammond & \\
\hline K.S. Tollefson & \\
\hline B.G. Erlandson & \\
\hline J.F. Bores & \\
\hline C.E. Grenard & \\
\hline Tom Conrads & \\
\hline A.F. Choho & \\
\hline
\end{tabular}

From

Thomas H. May

\begin{tabular}{|c|c|c|c|c|}
\hline & \multicolumn{4}{|c|}{ ECN No. N/A } \\
\hline MSIN & $\begin{array}{c}\text { Text } \\
\text { With All } \\
\text { Attach. }\end{array}$ & Text Only & $\begin{array}{l}\text { Attach.l } \\
\text { Appendix } \\
\text { Only }\end{array}$ & $\begin{array}{c}\text { EDT/ECN } \\
\text { Only }\end{array}$ \\
\hline$R 2-58$ & $x$ & & & \\
\hline $\mathrm{R} 1-56$ & $x$ & & & \\
\hline s5-05 & $x$ & & & \\
\hline S5-05 & $x$ & & & \\
\hline T4-07 & $x$ & & & \\
\hline$R 2-58$ & $x$ & & & \\
\hline $\mathrm{S} 2-48$ & $x$ & & & \\
\hline $\mathrm{s} 2-48$ & $x$ & & & \\
\hline$R 3-25$ & $\mathrm{x}$ & & & \\
\hline$R 3-25$ & $x$ & & & \\
\hline s5-13 & $\mathrm{x}$ & & & \\
\hline$S 2-48$ & $\mathrm{x}$ & & & \\
\hline $53-73$ & $\mathrm{x}$ & & & \\
\hline $\mathrm{R} 2-58$ & $x$ & & & \\
\hline $\mathrm{R} 2-12$ & $x$ & & & \\
\hline R2-11 & $x$ & & & \\
\hline $\mathrm{R} 2-11$ & $x$ & & & \\
\hline s5-55 & $\mathrm{x}$ & & & \\
\hline $\mathrm{T} 2-11$ & $x$ & & & \\
\hline R3-73 & $x$ & & & \\
\hline R3-73 & $x$ & & & \\
\hline $57-07$ & $x$ & & & \\
\hline S7-86 & $x$ & & & \\
\hline s7-01 & $\mathrm{x}$ & & & \\
\hline$s 6-14$ & $x$ & & & \\
\hline $\mathrm{R} 1-49$ & $x$ & & & \\
\hline $\mathrm{R} 1-51$ & $x$ & & & \\
\hline $\mathrm{R} 1-51$ & $x$ & & & \\
\hline $\mathrm{R} 2-89$ & $x$ & & & \\
\hline $\mathrm{R} 3-73$ & $x$ & & & \\
\hline $\mathrm{R} 3-73$ & $x$ & & & \\
\hline R3-73 & $x$ & & & \\
\hline
\end{tabular}

Page 1 of 1

Date $1 / 25 / 00$

EDT No. 628255

ECN No. N/A

Appendix

Only 